\title{
New magnetobiostratigraphic results from the Ladinian of the Dolomites and implications for the Triassic geomagnetic polarity timescale
}

\author{
Matteo Maron $^{\mathrm{a}, *}$, Giovanni Muttoni ${ }^{\mathrm{a}}$, Manuel Rigo ${ }^{\mathrm{b}, \mathrm{c}}$, Piero Gianolla ${ }^{\mathrm{d}}$, Dennis V. Kent ${ }^{\mathrm{e}, \mathrm{f}}$ \\ ${ }^{a}$ Department of Earth Sciences “Ardito Desio", University of Milano, via Mangiagalli 34, 20133 Milano, Italy \\ ${ }^{\mathrm{b}}$ Department of Geosciences, University of Padova, via Gradenigo 6, 35131 Padova, Italy \\ ${ }^{\mathrm{c}}$ Institute of Geosciences and Earth Resources, Consiglio Nazionale delle Ricerche (CNR), via Gradenigo 6, 35131 Padova, Italy \\ ${ }^{\mathrm{d}}$ Department of Physics and Earth Sciences, University of Ferrara, via Saragat 1, 44122 Ferrara, Italy \\ ${ }^{\mathrm{e}}$ Department of Earth and Planetary Sciences, Rutgers University, Piscataway, NJ 08854, USA \\ ${ }^{\mathrm{f}}$ Lamont-Doherty Earth Observatory, Columbia University, Palisades, NY 10964, USA
}

\section{A R T I C L E I N F O}

\section{Keywords:}

Magnetostratigraphy

Geochronology

Middle Triassic

$\mathrm{U}-\mathrm{Pb}$ dating

\begin{abstract}
A B S T R A C T
We investigated for magnetostratigraphy the Rio Nigra and Rio Frommer stratigraphic sections from Alpe di Siusi/Seiser Alm (Dolomites, northern Italy) in order to improve the calibration of the Triassic time scale. Both sections are characterized by ammonoid and conodont associations typical of Longobardian (late Ladinian, Middle Triassic) age. Moreover, the Rio Nigra section is constrained by a U-Pb zircon date of $237.77 \pm 0.05 \mathrm{Ma}$. Building on the recently verified Newark-Hartford astrochronological polarity timescale for the Late Carnian-Rhaetian (plus the Hettangian) and through magnetostratigraphic correlations of an updated inventory of Tethyan marine stratigraphic sections from the literature, some of which are provided with $\mathrm{U}-\mathrm{Pb}$ zircon age constraints, we propose a revised Geomagnetic Polarity Time Scale for the entire Triassic.
\end{abstract}

\section{Introduction}

The continuous addition of relevant magnetostratigraphic, radiometric, and astrochronologic age data warrant an update of the Triassic geomagnetic polarity timescale (GPTS). An astrochronological polarity timescale (APTS) for the Early-Middle Triassic has been recently obtained through astronomically-tuned magnetostratigraphic sections from South China (Li et al., 2016, 2018). The magnetostratigraphy of the Late Triassic has been improved with studies at Pignola-2 (Carnian; Maron et al., 2017), Wayao (Carnian; Zhang et al., 2015), and PignolaAbriola (Norian-Rhaetian; Maron et al., 2015; Rigo et al., 2016), and their correlations to the reference Newark-Hartford APTS (Carnian-Hettangian; e.g., Kent et al., 2017), which has been recently confirmed by new U-Pb zircon dates from the Petrified Forest drill core (Kent et al., 2018). The central thread of the Middle Triassic GPTS derives from radiometrically-calibrated magnetostratigraphic sections in the Dolomites of northern Italy (e.g., Muttoni et al., 2004a), where additional U-Pb zircon dates have recently become available from tuff layers at Seceda (239.04 $\pm 0.10 \mathrm{Ma}, 240.28 \pm 0.09 \mathrm{Ma}, 240.58 \pm 0.13 \mathrm{Ma}$; Wotzlaw et al., 2018) and Rio Nigra (237.77 $\pm 0.05 \mathrm{Ma}$; Mietto et al., 2012). In particular, Mietto et al. (2012) used the U-Pb date from the
Rio Nigra section, in conjunction with available geochronological data from the late Ladinian-Carnian and estimates of regional sediment accumulation rates, to derive an age of $\sim 237 \mathrm{Ma}$ for the Carnian base, older than in previous timescales (e.g., Hounslow and Muttoni, 2010).

The aim of this study was to improve the chronology of the Middle Triassic by conducting a magnetostratigraphic study of the U-Pb-calibrated Rio Nigra section as well as of the largely coeval Rio Frommer section from the Dolomites. These new data are used in conjunction with data from a selection of 33 Tethyan marine sections (Fig. 1A, B) from the literature (10 of them from the Southern Alps; Fig. 2A), constrained by an updated inventory of radiometric age data and key biostratigraphic events useful to define stage boundaries, to construct an updated GPTS spanning from the recently recalibrated age of the Permian/Triassic boundary (Burgess et al., 2014) to the Carnian (Late Triassic). This GPTS is then appended to the Late Triassic Newark APTS (Kent et al., 2017 and references therein; Fig. 1A, B) where stage boundaries are defined by correlations to Tethyan marine sections some of which of recent publication. Our Triassic GPTS is then discussed in comparison with previous timescales (e.g., Szurlies, 2007; Hounslow and Muttoni, 2010; Li et al., 2018).

\footnotetext{
* Corresponding author.

E-mail addresses: matteo.maron@unimi.it (M. Maron), giovanni.muttoni1@unimi.it (G. Muttoni), manuel.rigo@unipd.it (M. Rigo), piero.gianolla@unife.it (P. Gianolla),dvk@ldeo.columbia.edu (D.V. Kent).
} 

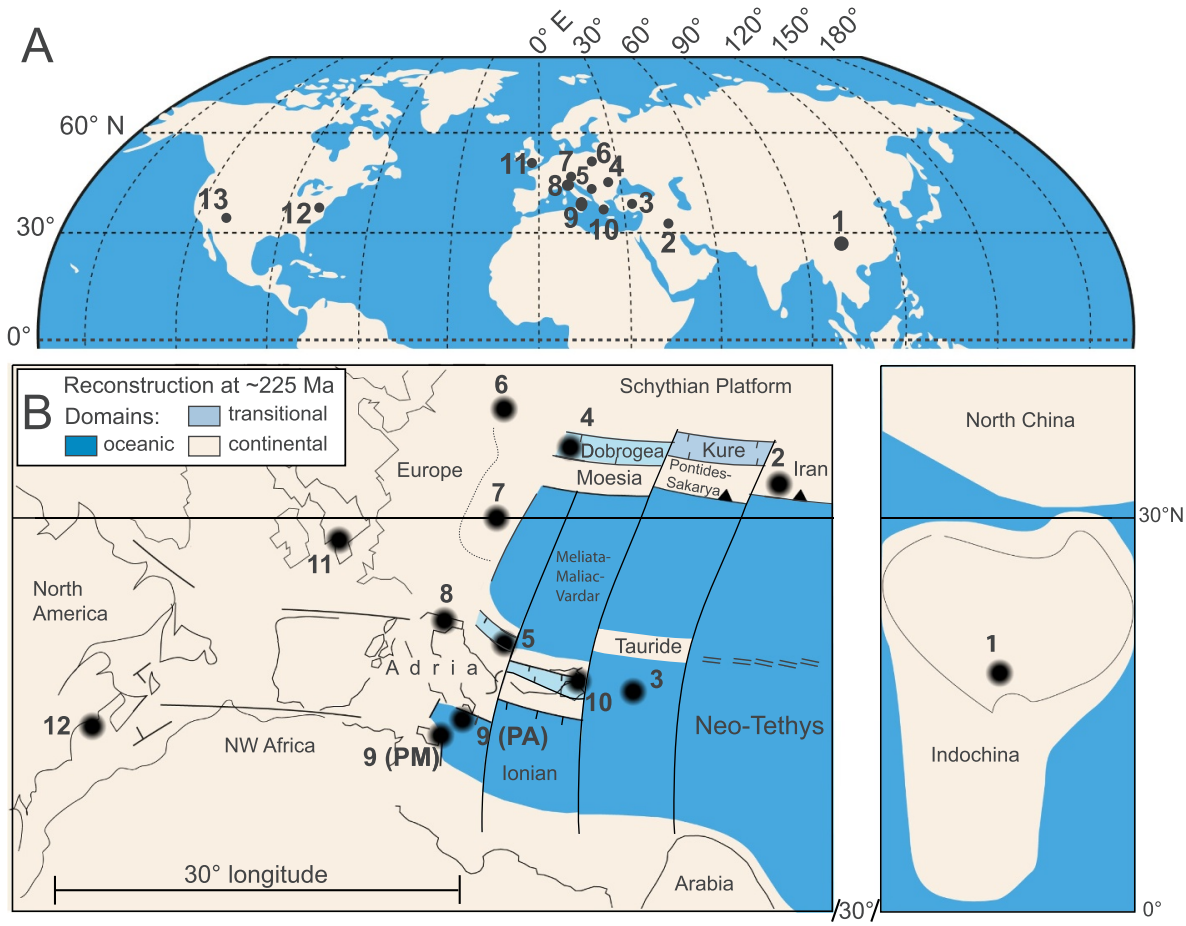

Fig. 1. Panel A: Global map with the location of the stratigraphic sections discussed in the text. Panel B: Paleogeographic reconstruction of Pangea and the Tethys Ocean in the earliest Late Triassic at $\sim 225 \mathrm{Ma}$ (from Muttoni et al., 2015). Due to general northward motion of Pangea during the Triassic, stratigraphic sections older than $225 \mathrm{Ma}$, such as the Early Triassic sections from South China, were located closer to the paleoequator. Magnetostratigraphic sections discussed in the text are indicated by numbers (legend in figure).

1. South China 2. Abadeh 3. Bolücektasi Tepe 4. Deşli Caira 5. Kçira 6. Poland 7. Northern Calcareous Alps 8. Southern Alps 9. Pignola-Abriola, Pignola-2 (PA); Pizzo Mondello (PM) 10. Aghia Triada

11. St. Audrie's Bay 12. Newark 13. Petrified Forest

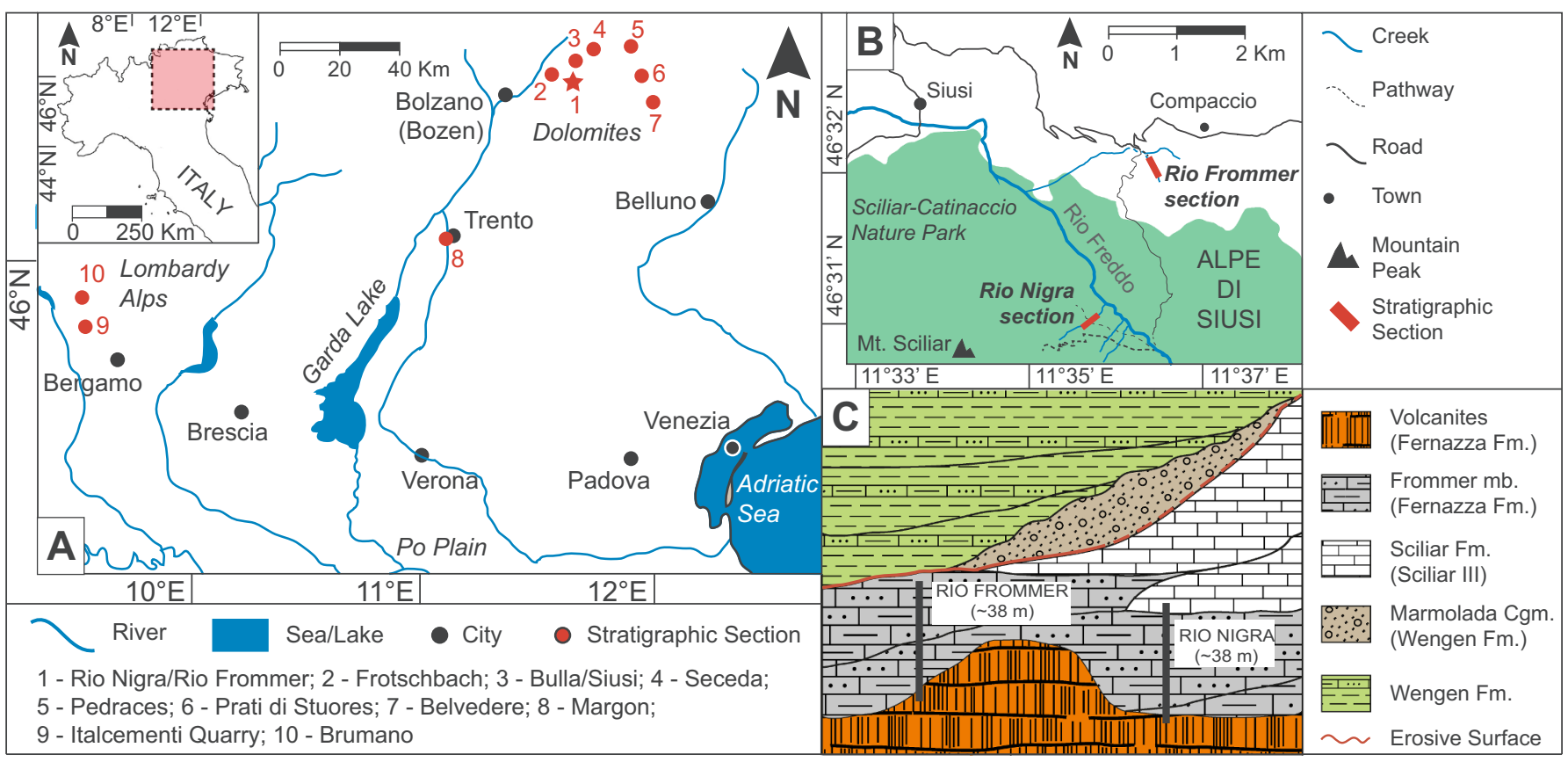

Fig. 2. Panel A: Map of north-eastern Italy, with position of the main stratigraphic sections from the Southern Alps. Panel B: Map of the Alpe di Siusi/Seiser Alm area, Dolomites, Italy. The Rio Frommer stratigraphic section is located near the village of Compaccio/Compatsch and the Rio Nigra section closer to the Sciliar/Schlern massif, within the Sciliar-Catinaccio/Schlern-Rosengarten Nature Park. Panel C: Stratigtraphic framework of Alpe di Siusi in which are represented the boundaries between the Fernazza Fm. (Volcanites and Frommer member), the Sciliar Fm., and the Wengen Fm. (including the Marmolada Conglomerate).

\section{Stratigraphy of Rio Nigra and Rio Frommer sections}

The Rio Nigra section (coordinates: $46^{\circ} 30^{\prime} 56.1^{\prime \prime} \mathrm{N}$; $11^{\circ} 35^{\prime} 43^{\prime \prime} \mathrm{E}$ ) is located in the Alpe di Siusi on the north-eastern flank of Mount Sciliar/
Schlern along the Rio Nigra Creek (Fig. 2B). The section is $\sim 38 \mathrm{~m}$-thick and straddles the Frommer member of the Fernazza Formation (Gianolla et al., 1998; Stefani et al., 2010; Mietto et al., 2012; Bernardi et al., 2018) (Fig. 3A). It starts with pillow lavas at the base overlain by 


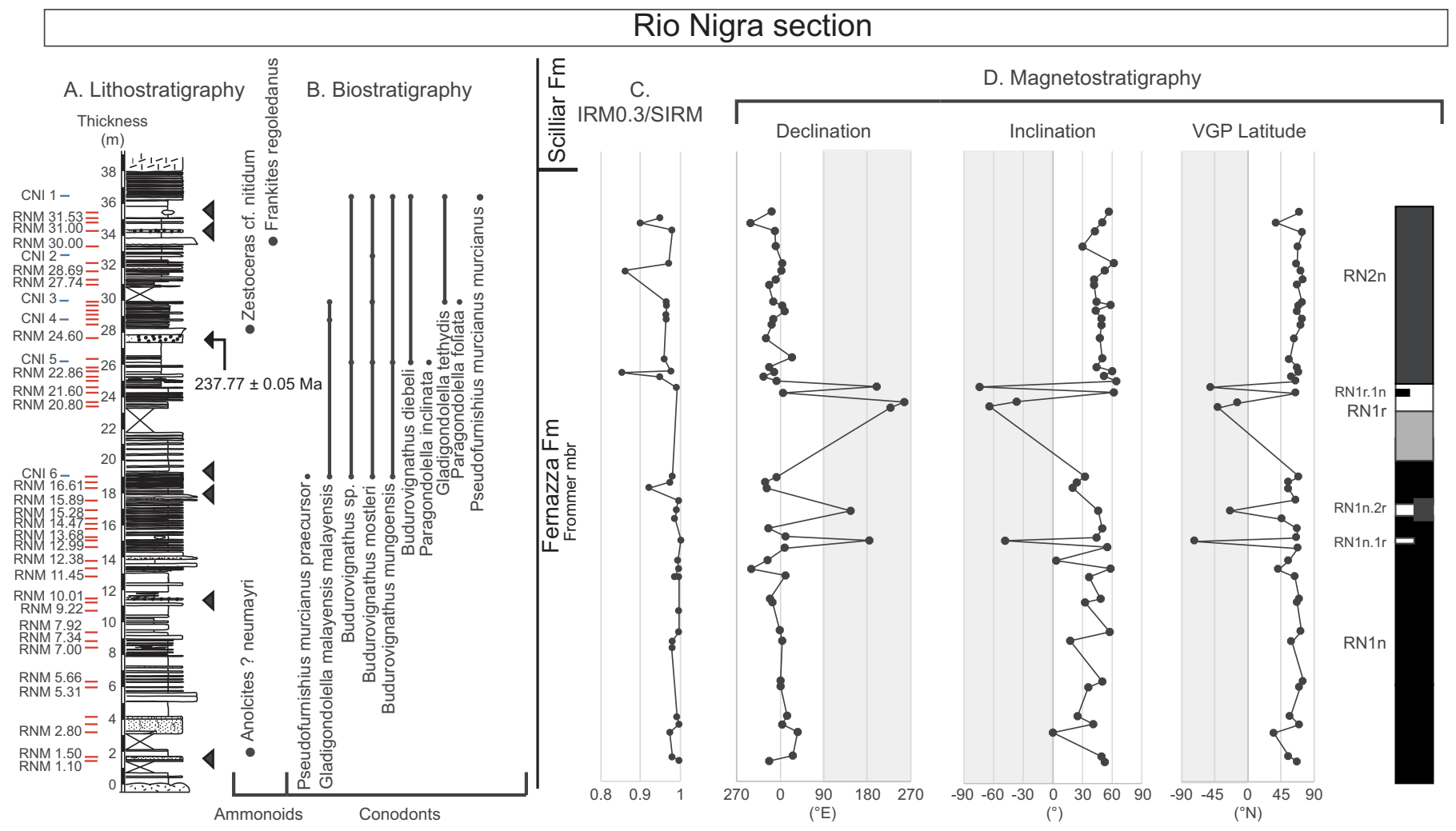

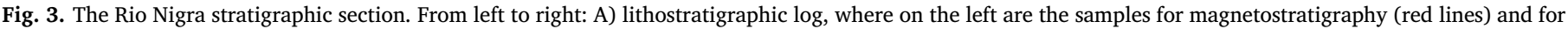

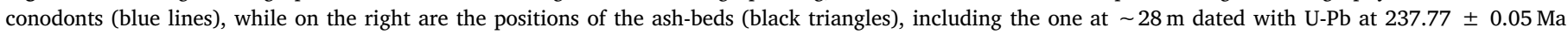

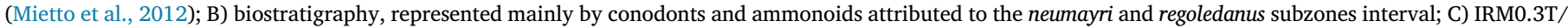

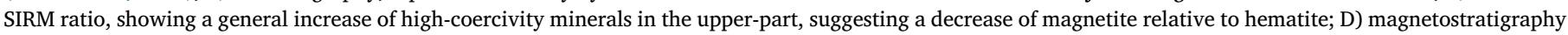

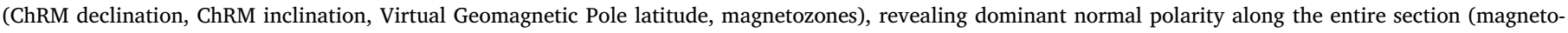
zones RN1n, RN2n), punctuated by a reverse magnetozone (RN1r) and three single-sample reverse intervals (RN1n.1r, RN1n.2r, RN1r.1n).

volcaniclastic sandstones and marls. The basalt-sediment contact is characterized by pockets sometimes bearing ammonoids. Upsection, marls and shales become dominant, intercalated with limestones and volcaniclastic calcarenites. The upper part is enriched in bioclastic calcarenites that are in sharp upper contact with the slope breccias of the Sciliar-III carbonate platform. A tuff layer at $\sim 27.5 \mathrm{~m}$ yielded a high precision U-Pb detrital zircon date of $237.77 \pm 0.05 \mathrm{Ma}$ (Mietto et al., 2012) (Fig. 3A). The Rio Nigra section is characterized by the presence of conodonts Gladigondolella malayensis malayensis, G. tethydis, Budurovignathus mostleri, B. mungoensis, B. diebeli, Paragondolella inclinata, $P$. foliata, Pseudofurnishius murcianus praecursor and $P$. murcianus murcianus (Figs. 3B; 4). This association suggests a late Ladinian age, confirmed by the occurrence of ammonoids Anolcites? neumayri, Zestoceras cf. nitidum and Frankites regoledanus attributed altogether to the neumayri and regoledanus Subzones (De Zanche et al., 1993; Mietto and Manfrin, 1995; Broglio Loriga et al., 1999; Mietto et al., 2008; Mietto et al., 2012).

The Rio Frommer section (coordinates: $46^{\circ} 32^{\prime} 16^{\prime \prime} \mathrm{N} ; 11^{\circ} 36^{\prime} 20.6^{\prime \prime}$ E) crops out along the Rio Frommer Creek, $\sim 1 \mathrm{~km}$ southwest of the village of Compaccio/Compatsch in the Alpe di Siusi (Fig. 2B). The section encompasses $\sim 40 \mathrm{~m}$ of strata pertaining to the Frommer member of the Fernazza Formation (Fig. 5A). It starts with basalts overlain by volcaniclastic shales intercalated with marls and fine sandstones. The basal contact with the lavas is marked by a chaotic level. Marls and shales become more abundant upsection. A few tuff layers are present. Ammonoids recovered in the basal portion of the Rio Frommer section (Anolcites? neumayri, Zestoceras cf. nitidum, Protrachyceras ladinum, Frankites sp., and Frankites regoledanus; Fig. 5B) are attributed to the neumayri and regoledanus Subzones of late Ladinian age, similar to Rio Nigra.

\section{Paleomagnetism}

\subsection{Methods}

A total of 52 and 28 standard $(10 \mathrm{cc})$ drill core samples have been recovered from the Rio Nigra and Rio Frommer sections respectively and analyzed at the Alpine Laboratory of Paleomagnetism of Peveragno (Italy). Samples were thermally demagnetized in steps of $50{ }^{\circ} \mathrm{C}-25^{\circ} \mathrm{C}$ from room temperature up to $675^{\circ} \mathrm{C}$ with an ASC Scientific TD48 oven. The natural remanent magnetization (NRM) was measured after each step with a 2G Enterprises 755 DC-SQUID cryogenic magnetometer located in a magnetically shielded room. The directions of the NRM were plotted on standard vector end-point demagnetization diagrams (Zijderveld, 1967) and the characteristic remanent magnetization (ChRM), where present, was isolated with standard principal component analysis of selected data. Isothermal remanent magnetization (IRM) acquisition experiments were performed using an ASC Scientific IM-10-30 impulse magnetizer and an AGICO JR-6 spinner magnetometer on 8 samples from Rio Nigra and 7 samples from Rio Frommer. Thermal demagnetization of a three-component IRM (Lowrie, 1990) was performed on a subset of the samples from both sections adopting $2.5 \mathrm{~T}, 0.4 \mathrm{~T}$ and $0.12 \mathrm{~T}$ orthogonal fields. The relative concentration of low vs. high coercivity minerals was obtained by computing the ratio of IRM imparted at $0.3 \mathrm{~T}$ and at a saturating $1.0 \mathrm{~T}$ fields $\left(\mathrm{IRM}_{0.3 \mathrm{~T}} / \mathrm{SIRM}\right)$. Finally, the low-field magnetic susceptibility $(\kappa)$ and the anisotropy of the magnetic susceptibility (AMS) were measured with an AGICO KLY-3 Kappabridge. 


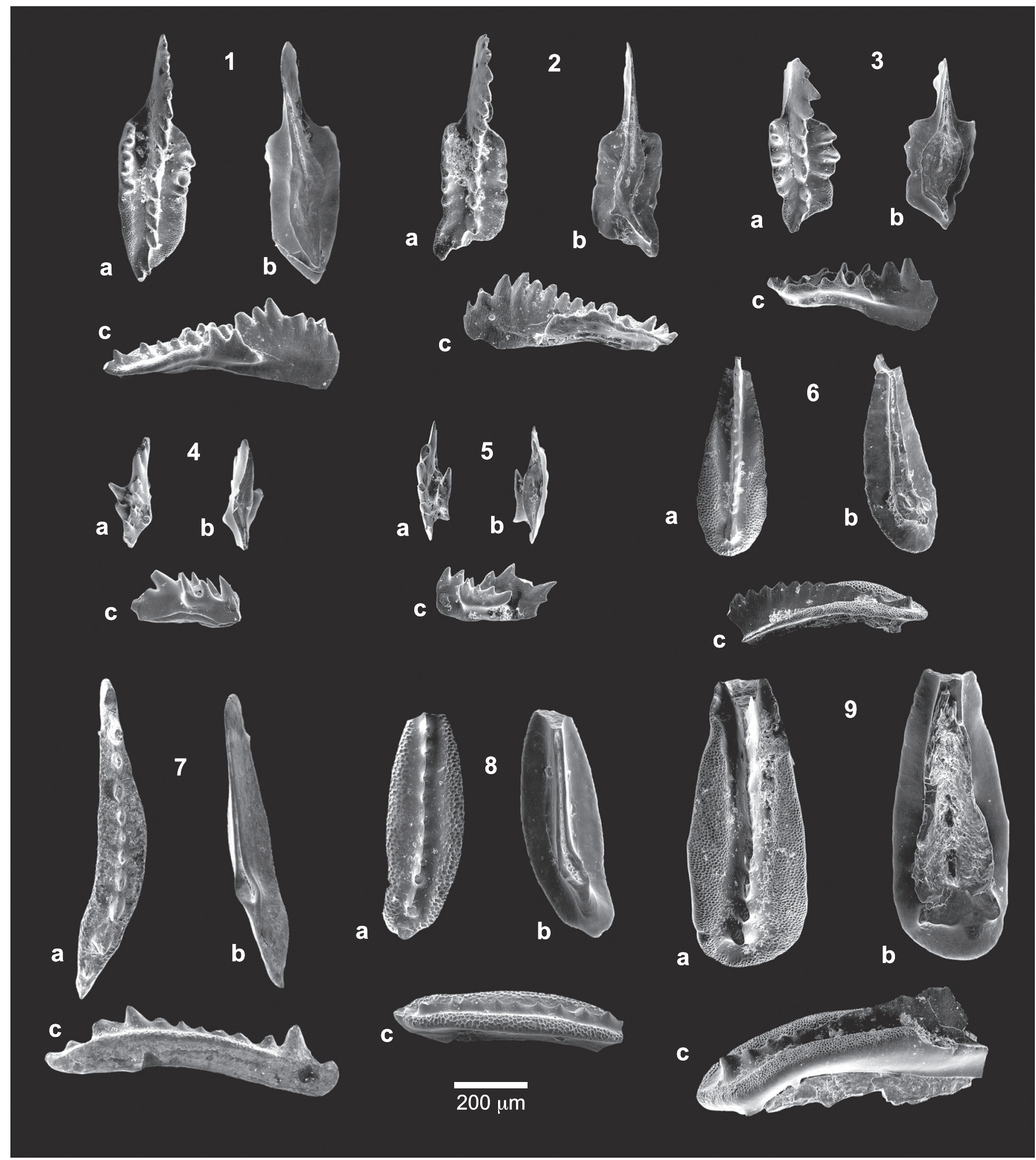

Fig. 4. Conodonts of the Rio Nigra section (scale bar $=200 \mu \mathrm{m})$. A is for upper view, B for lower view, and C for lateral view. 1) Budurovignathus mostleri (CNI6); 2) Budurovignathus mungoensis (CNI6); 3) Budurovignathus diebeli (CNI1); 4) Pseudofurnishius murcianus praecursor (CNI6); 5) Pseudofurnishius murcianus murcianus (CNI1); 6) Paragondolella foliata (CNI3); 7) Gladigondolella tethydis (CNI1); 8) Gladigondolella malayensis malayensis (CNI4); 9) Paragondolella inclinata (CNI5).

\subsection{Magnetic properties}

Values of $\kappa$ and NRM are relatively high in the lower part of both sections just above the lavas (Figs. 3A, 5A), due to high concentrations of volcanigenic material. Upsection, $\kappa$ and NRM values tend to decrease suggesting a decrease of volcaniclastic input; the $\mathrm{IRM}_{0.3 \mathrm{~T}} / \mathrm{SIRM}$ values are close to 1 in the upper part of the Frommer member in both sections (Figs. 3C, 5C), suggesting the presence of a dominant low-coercivity magnetic phase. Above level $\sim 25 \mathrm{~m}$ at Rio Nigra (Fig. 3C) and level $\sim 33 \mathrm{~m}$ at Rio Frommer (Fig. $5 \mathrm{C}$ ), $\mathrm{IRM}_{0.3 \mathrm{~T}} / \mathrm{SIRM}$ values slightly decrease to around 0.85 , indicating a moderate increase in high-coercivity minerals. 


\section{Rio Frommer section}

A. B. $\quad$ C.

Lithostratigraphy Biostratigraphy IRM0.3/SIRM

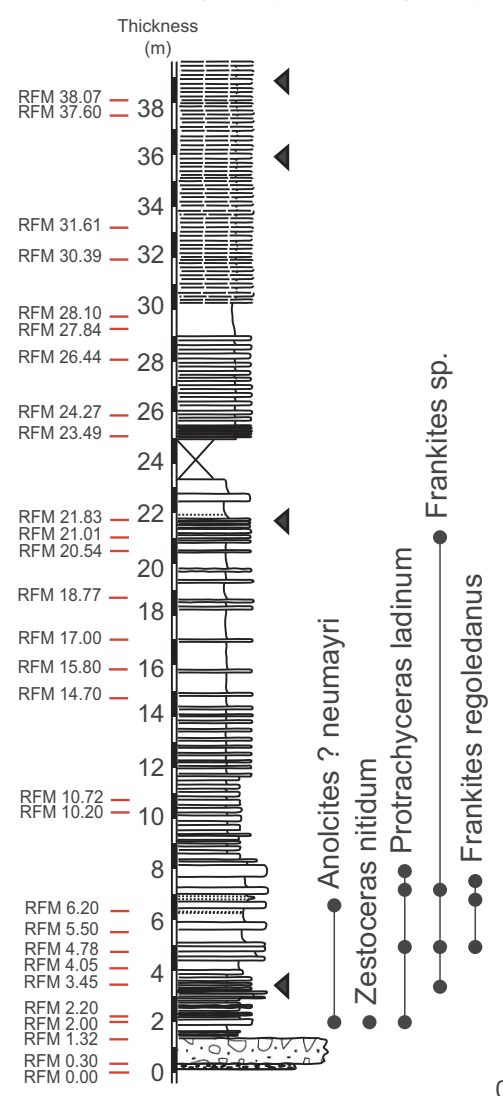

0.8
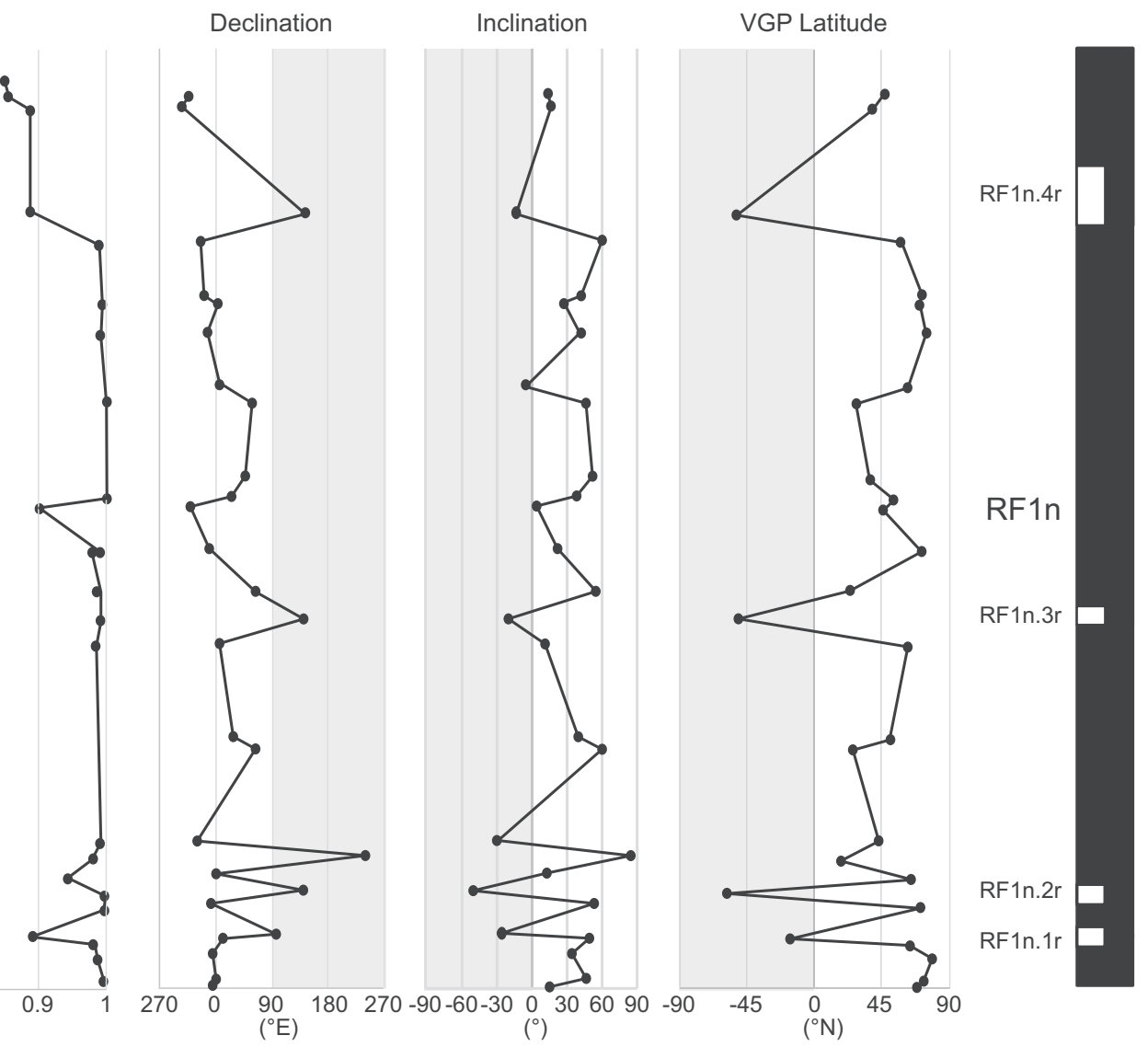

Fig. 5. The Rio Frommer stratigraphic section. From left to right: A) lithostratigraphy, where samples for magnetostratigraphy are on the left of the stratigraphic log, and ash-beds are indicated on the right (black triangles); B) biostratigraphy, represented exclusively by ammonoids attributed to the neumayri and regoledanus subzones interval; C) IRM0.3T/SIRM ratio, showing a general increase of high-coercivity minerals in the upper part, suggesting a decrease of magnetite relative to hematite; D) magnetostratigraphy (ChRM declination, ChRM inclination, VGP [Virtual Geomagnetic Pole] latitude, magnetozones), showing only one normal magnetozone (RF1n), with four single-sample aberrant direction (reverse polarity intervals?) labeled RF1n.1r, RF1n.2r, RF1n.3r, and RF1n.4r.

The IRM acquisition curves of samples from both sections (Fig. 6, samples labeled with prefix 'RNM' for Rio Nigra and 'RFM' for Rio Frommer followed by a suffix indicating stratigraphic position) tend to saturate around $0.1-0.2 \mathrm{~T}$ indicating the presence of a low coercivity mineral. Samples RFM37.60 and RNM21.16 tend to saturate around $1.7-2 \mathrm{~T}$ indicating the presence of a higher coercivity mineral phase. The three-axes IRM experiments (Fig. 7) show that the magnetization is generally carried by the $0.12 \mathrm{~T}$ curve that shows maximum unblocking temperatures of $\sim 575^{\circ} \mathrm{C}$, indicating the dominant presence of magnetite in agreement with most of the IRM acquisition curves. In a few cases (e.g., sample RNM28.69), the $2.5 \mathrm{~T}$ curve seems to persists above $575^{\circ} \mathrm{C}$, possibly indicating minor contributions from (fine-grained?) hematite, in agreement with the subsidiary high coercivity component observed in the IRM acquisition curves.

The AMS data indicate that samples from both sections are characterized by relatively scattered principal susceptibility axes and very low degrees of anisotropy ( $\mathrm{P}<1.1$ ) (Fig. S1, Supplemental material). Most of the Rio Frommer samples show oblate anisotropy ellipsoids, whereas Rio Nigra ellipsoids are either oblate or prolate (Fig. S1, Supplemental material), but in any case, even in the prolate cases, the degree of anisotropy is very low. These observations tend to exclude major tectonic overprints (e.g., pervasive compression-induced foliation) on the studied samples.

\subsection{Magnetostratigraphy}

Bipolar ChRM component directions, oriented predominantly northand-down or more rarely south-and-up in in situ coordinates, have been isolated from $\sim 150^{\circ} \mathrm{C}$ to $\sim 550{ }^{\circ} \mathrm{C}$ in 47 of 52 samples from Rio Nigra and in all (28) samples from Rio Frommer (Fig. 8) (see also Supplemental Table S1). The ChRM directions do not coincide with the geocentric axial dipole (GAD) field in in situ coordinates (Fig. 9), indicating that any overprints of recent origin have been successfully removed. The mean ChRM direction in tilt-corrected coordinates, calculated by applying Fisher statistics (Fisher, 1953) on $n=75$ ChRM directions from both sections, yields a paleomagnetic pole (Table 1) that lies close to the paleopole from the Ladinian Buchenstein beds of the Dolomites (Muttoni et al., 2004a, 2013), supporting a primary origin of the ChRM.

A virtual geomagnetic pole (VGP) was calculated for each ChRM component direction in tilt corrected coordinates. Assuming that the Dolomites were located in the northern hemisphere (Muttoni et al., 2004a), the latitude of the sample VGP relative to the north paleomagnetic pole (positive for normal, negative for reverse polarity) was used for interpreting the polarity stratigraphy. Each magnetozone is prefixed by the acronym for the source of the magnetostratigraphy ("RN" for Rio Nigra, "RF" for Rio Frommer). The latitudes of the sample VGPs define a sequence of 3 magnetozones at Rio Nigra (from RN1n to RN2n; Fig. 3D) and one magnetozone at Rio Frommer (RF1n), in which 


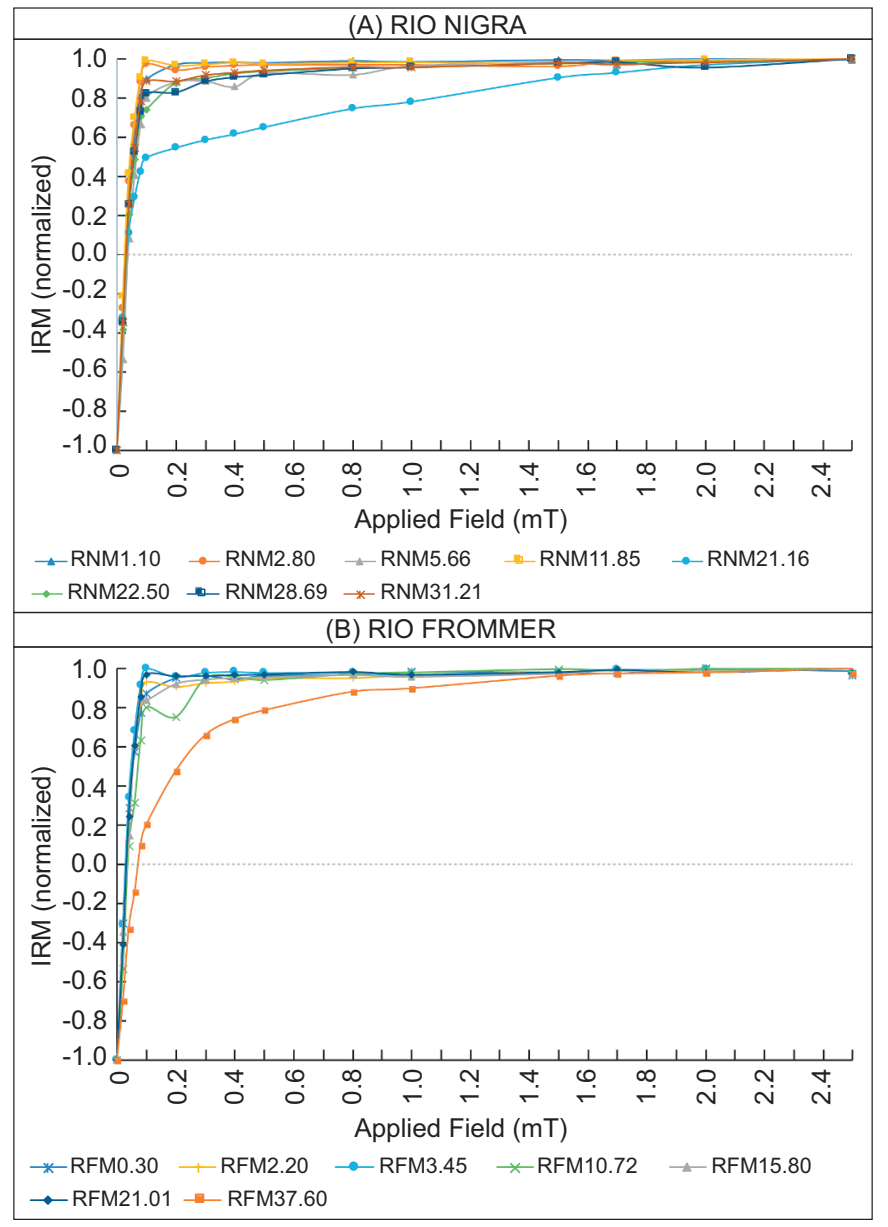

Fig. 6. Normalized IRM backfield curves of a set of selected samples from Rio Nigra (Panel A) and Rio Frommer (Panel B). Samples labeled with prefix 'RNM' for Rio Nigra and 'RFM' for Rio Frommer followed by a suffix indicating stratigraphic position. Most of the samples show saturation around 100-200 mT consistent with magnetite, except for RNM21.16 and RFM37.60 that tend to saturate at much higher fields because of the presence of high coercivity minerals (probably hematite).

single-sample reverse sub-magnetozones (RF1n.1r, RF1n.2r, RF1n.3r, RF1n.4r) are embedded (Fig. 5D).

The two sections have been tentatively correlated using magnetostratigraphy and rock-magnetic properties (Fig. 10). Reverse magnetozone RN1r has been correlated to RF1n.4r and reverse sub-magnetozone RN1n.1r to RF1n.3r (Fig. 10). This correlation matches the trend of the IRM $\mathrm{IO.3T}_{\text {T }} / \mathrm{SIRM}$ curves observed in both sections and interpreted as a slight increase of high-coercivity minerals in the upper part of the Frommer member (Fig. 10). The $\mathrm{IRM}_{0.3 \mathrm{~T}} / \mathrm{SIRM}$ spikes probably mark a (relative) major input of high-coercivity minerals as hematite possibly due to the extrusion and consequent low temperature oxidation of subaerial volcanics (e.g. Holmes, 1995; Planke et al., 1999). Ammonoid levels are too sparse to be used as meaningful correlation tools or to erect subzone boundaries; for example, the levels in the two sections with $F$. regoledanus are not necessarily correlative. The magnetic correlation implies complex onlap geometries of sedimentary layers with the underlying basalts, in agreement with the general tectonostratigraphic setting of the area characterized by morphologically complex volcanic structures onlapped and sutured by volcaniclastic packages of extremely variable thicknesses (Fig. 2C). Accordingly, the Rio Nigra and Rio Frommer sections probably represent the same Neumayri-Regoledanus stratigraphic interval straddling the $\mathrm{U}-\mathrm{Pb}$ detrital zircon age of $237.77 \pm 0.05 \mathrm{Ma}$ (Fig. 10).

\section{An updated Triassic Geomagnetic Polarity Time Scale}

The U-Pb-calibrated magnetostratigraphy of the Rio Nigra and Rio Frommer sections represents a valuable contribution to the evolving Triassic GPTS, which we reappraise after Hounslow and Muttoni (2010) using an updated inventory of Early-Middle Triassic age-calibrated Tethyan marine magnetostratigraphies from the literature that can be appended to the Late Triassic Newark continental APTS (Fig. 1A, B).

We initially constructed a visually coherent correlation grid where individual sections are scaled in the depth domain using magnetozone thickness usually expressed relative to the thickest and most continuous (reference) sections for each stratigraphic interval of the Triassic. In this correlation scheme, subdivided into three separate figures for better visualization (Figs. 11-13), magnetostratigraphic correlation lines should ideally be horizontal, albeit this geometry is not always attainable due to variations in sediment accumulation rates within some of the sections used in the compilation. Within this correlation grid, we correlated the magnetostratigraphy of individual sections onto the reference sections (Meishan [Li and Wang, 1989] and Guandao [Lehrmann et al., 2006; Li et al., 2018] for the Early-Middle Triassic, Seceda [Muttoni et al., 2004a] and Mayerling [Gallet et al., 1994, 1998] for the Middle-Late Triassic, the Newark APTS [Kent et al., 2017, 2018] for the Late Triassic) using additional data from correlative ancillary sections, essentially key fossil datums useful to define (or improve the definition of) stage boundaries and extend the applicability of $\mathrm{U}-\mathrm{Pb}$ age data. In general, we opted to maintain the magnetostratigraphy of the reference sections as integral as possible to allow the traceability of the original data used to compile the final magnetic polarity timescale; however, focused insertions of missing or better defined magnetozones from ancillary sections have been performed where appropriate (and denoted by the different section acronyms).

The augmented reference sections in depth coordinates were then migrated to the time domain by linear stretching between U-Pb dated tie-points (see Table 2 for a summary of U-Pb dates) and, where possible, using astrochronology (Figs. 11-13, right column). Contrary to Hounslow and Muttoni (2010), Ogg (2012a) and Hounslow et al. (2018), we opted to maintain in the assembled magnetic polarity timescale the original magnetozone nomenclature of the constituent reference sections (e.g., SC for Seceda, etc.). This philosophy based on magnetostratigraphic correlations of reference sections under the assumption that sedimentation is a linear proxy of time differs from timescales erected assuming biozones of equal duration (Krystyn et al., 2002; Gallet et al., 2003; see also discussion in Muttoni et al., 2010 and Kent et al., 2017). Parenthetically, biostratigraphy enters our construction essentially to define stage boundaries but very moderately as a correlation tool. Also, we avoided segmenting sections by introducing gaps according to the apparent lack of recovery of a given biozone (Krystyn et al., 2002; Hounslow and Muttoni, 2010, Fig. 10) because it is hard to assess the duration of these postulated gaps.

The correlation grid is subdivided into three time intervals (Induan-Anisian, Anisian-Carnian, Carnian-Rhaetian) for clarity of visualization, as described below.

\subsection{Induan-Olenekian-Anisian (Early Triassic-early Middle Triassic)}

The magnetostratigraphy across the Permian/Triassic (Changhsingian/Induan) boundary is relatively well established (and dominated by normal polarity) at Meishan in China (Li and Wang, 1989), which is the GSSP for the base of the Triassic placed at the first occurrence (FO) of conodont Hindeodus parvus. At Meishan, the age of the boundary has been recently recalibrated at $251.90 \pm 0.02 \mathrm{Ma}$ by interpolating $\mathrm{U}-\mathrm{Pb}$ ages at $251.94 \pm 0.04 \mathrm{Ma}$ and $251.88 \pm 0.03 \mathrm{Ma}$ obtained respectively from a level $16 \mathrm{~cm}$ below and $12 \mathrm{~cm}$ above the level registering the FO of H. parvus (Burgess et al., 2014) (Fig. 11). This new recalibration updates the previous ages proposed by Mundil et al. (2004) and Shen et al. (2011). Correlative sections with a reliable 


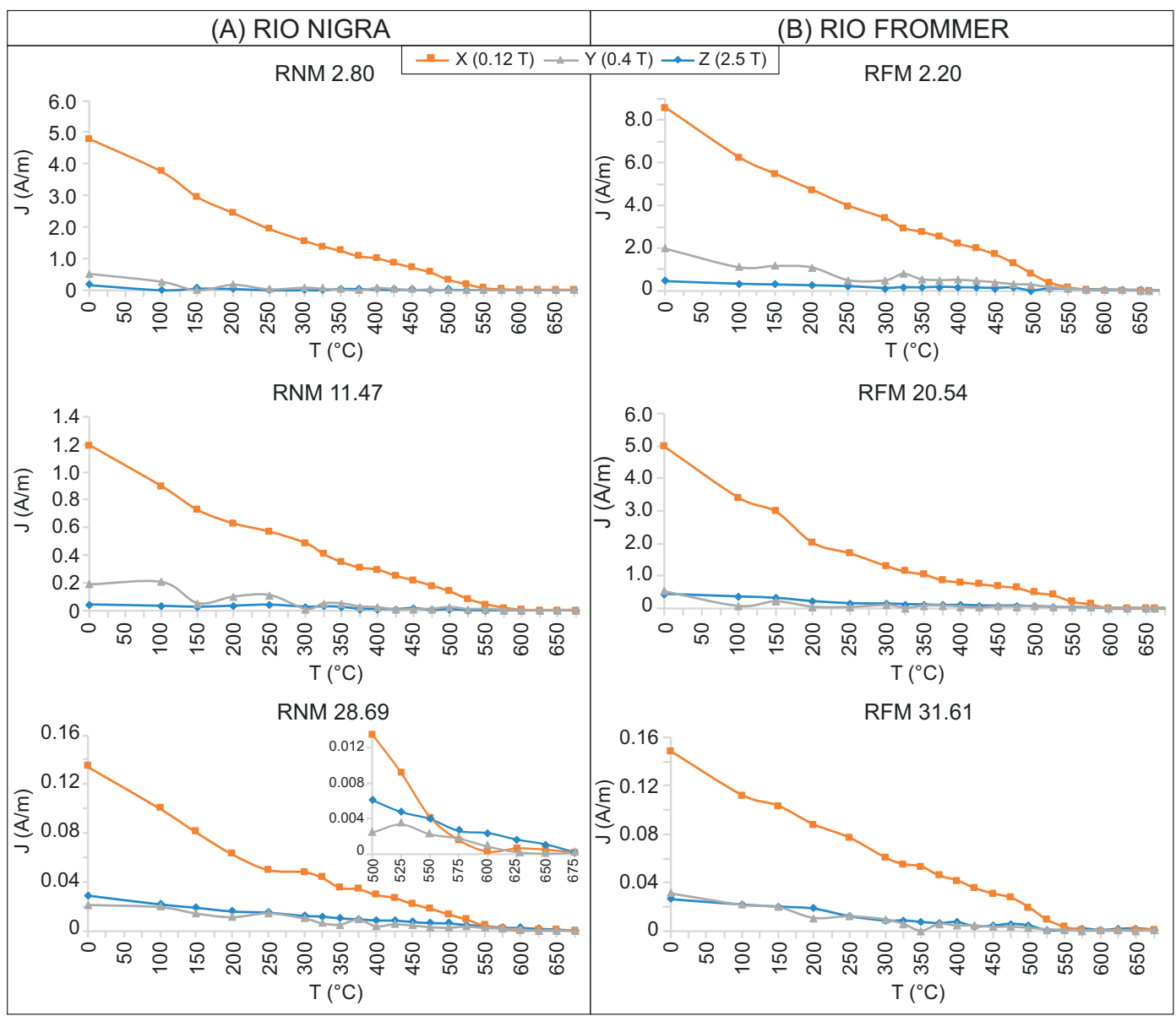

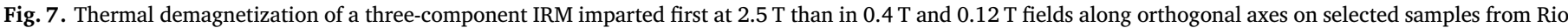

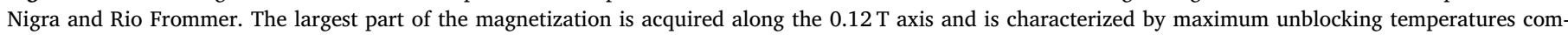

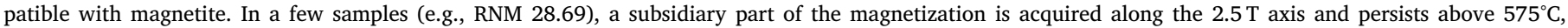
suggesting the presence of hematite.

magnetostratigraphy are Bulla/Siusi in Italy (Scholger et al., 2000), Abadeh in Iran (Gallet et al., 2000a), Hechuan in China (Steiner et al., 1989) and Shangsi in China (e.g. Steiner et al., 1989; Glen et al., 2009) (Fig. 11). At the Guandao section from China (Payne et al., 2004; Lehrmann et al., 2006), the Permian/Triassic boundary interval is characterized by a large unsampled shale interval, whereas the lower Chaohu section from China (Sun et al., 2007, 2009; Li et al., 2016; reported as Pingdingshan West in Hounslow and Muttoni, 2010) does not contain a biostratigraphic record of the boundary (e.g. Zhao et al., 2008; Sun et al., 2009) (Fig. 11).

The Induan/Olenekian boundary is placed in the lower Chaohu section at the FO of conodont Neospathodus waageni, which falls in a short normal polarity magnetozone within a dominant reverse polarity interval (Sun et al., 2007, 2009; Li et al., 2016). A correlative magnetobiostratigraphic pattern is observed also in the lower part of the Guandao section, from magnetozone GDL1 to GDL5 (Lehrmann et al., 2006) (Fig. 11). Following the cyclostratigraphy of the lower Chaohu section ( $\mathrm{Li}$ et al., 2016), based on $405 \mathrm{kyr}$ and $100 \mathrm{kyr}$ eccentricity cycles, and accepting an age for the Permian/Triassic boundary of $251.9 \mathrm{Ma}$ (Burgess et al., 2014), the Induan/Olenekian boundary should fall at $249.9 \mathrm{Ma}$ for a total duration of the Induan of $\sim 2 \mathrm{Myr}$ (Li et al., 2016).

However, there are some issues regarding the astronomically tuned lower Chaohu section. In Li et al. (2016), the cyclostratigraphy is calibrated with the U-Pb zircon interpolated date of $251.90 \pm 0.02 \mathrm{Ma}$ at Meishan (Burgess et al., 2014) through a questionable correlation. According to the original magnetostratigraphy, the base of the lower
Chaohu section is characterized by a short normal polarity zone encased in a dominant reverse polarity interval (Sun et al., 2009). Li et al. (2016) reinterpreted this polarity sequence and inserted a zone of uncertain polarity (without providing supportive information or experimental data) at the base of the section that they correlated to normal magnetozone ME3n at Meishan in order to use the age of 251.9 Ma as a tie-point for the cyclostratigraphy. In addition, at lower Chaohu the Permian/Triassic boundary is not clearly defined by biostratigraphy (it has been placed using the 'boundary stratigraphic set' of Peng et al. (2001) encompassing the boundary clay bed [Zhao et al., 2007, 2008; Sun et al., 2009]). An alternative option for the age of the Induan/ Olenekian boundary is provided by Galfetti et al. (2007) who obtained a U-Pb zircon date of $251.22 \pm 0.20 \mathrm{Ma}$ for a volcanic ash layer within the "Kashmirites densistriatus beds" of early Olenekian age (lower Euflemingites romunderi ammonoid Zone, considered mostly coeval to the FO of N. waageni in Canada [Orchard and Tozer, 1997; Orchard, 2008; Romano et al., 2013]) from the Luolou Formation of South China; this age estimate coupled with the recalibrated age of the Permian/Triassic boundary would imply a duration of the Induan of only $\sim 0.7 \mathrm{Myr}$.

Acknowledging the limitations illustrated above, we provisionally opt for the Li et al. (2016) solution (Induan/Olenekian boundary at $249.9 \mathrm{Ma}$ ) as we consider the uncertainties related to the trans-continental biostratigraphic correlations at the base of the Galfetti et al. (2007) solution possibly larger than the uncertainties related to the Meishan-lower Guandao correlation at the base of the Li et al. (2016) solution. Moreover, the U-Pb dates of Burgess et al. (2014) and Lehrmann et al. (2015) have been obtained through the EARTHTIME 


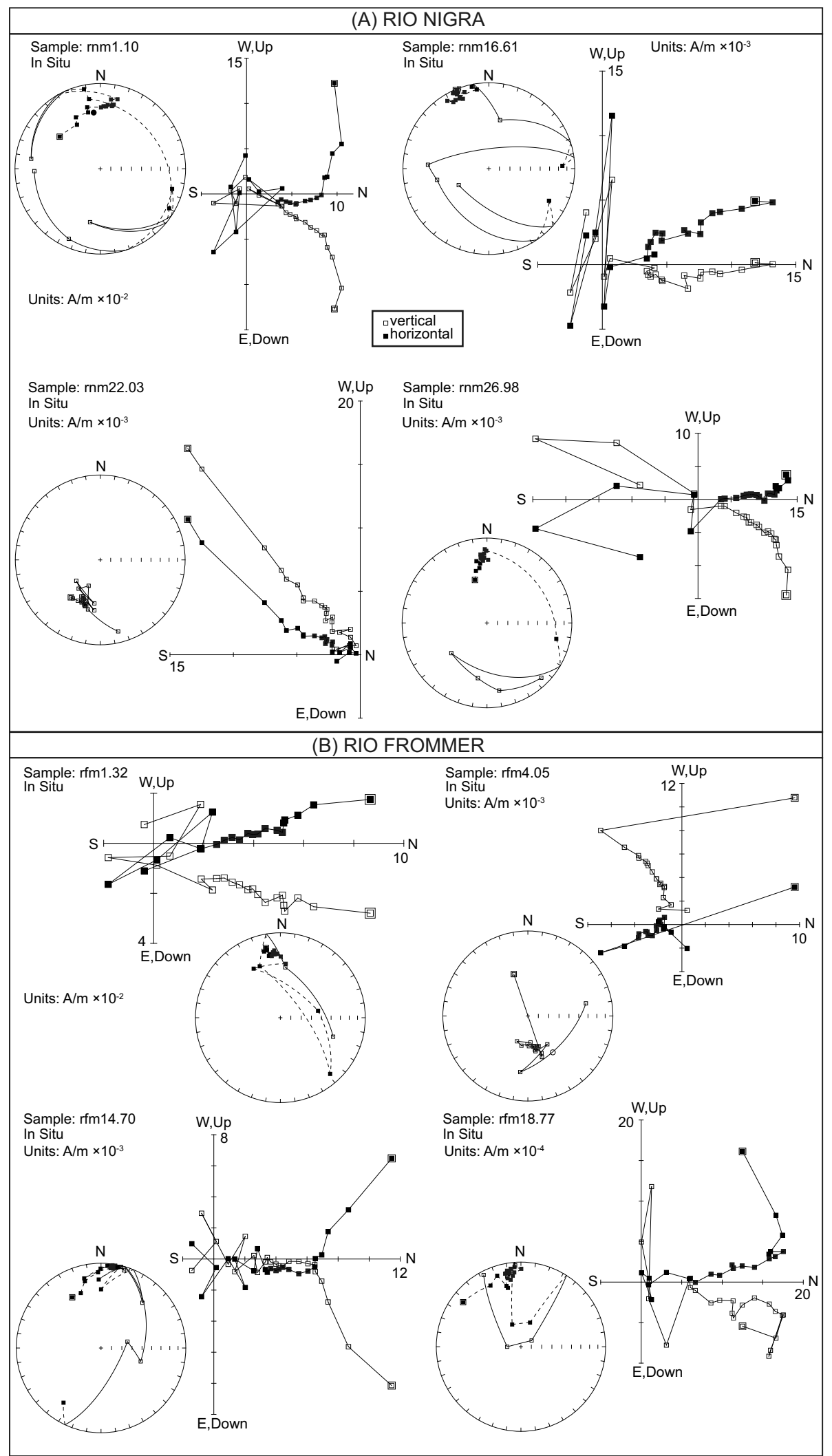

Fig. 8. Vector end-point NRM demagnetization diagrams and stereographic projections of representative samples from Rio Nigra (Panel A) and Rio Frommer (Panel B).

tracer solution, thus we prefer to avoid the comparison with the dates obtained with older tracers, as is the case with the Olenekian U-Pb zircon date of Galfetti et al. (2007). Even if we prefer the Li et al. (2016) option for the Induan/Olenekian boundary age, we would still update the correlation between lower Chaohu and Meishan without the introduction of purported magnetozones in the lower Chaohu section. Using also the magnetostratigraphy of Shangsi (e.g. Steiner et al., 1989; Glen et al., 2009) to test the correlation between Meishan and lower 


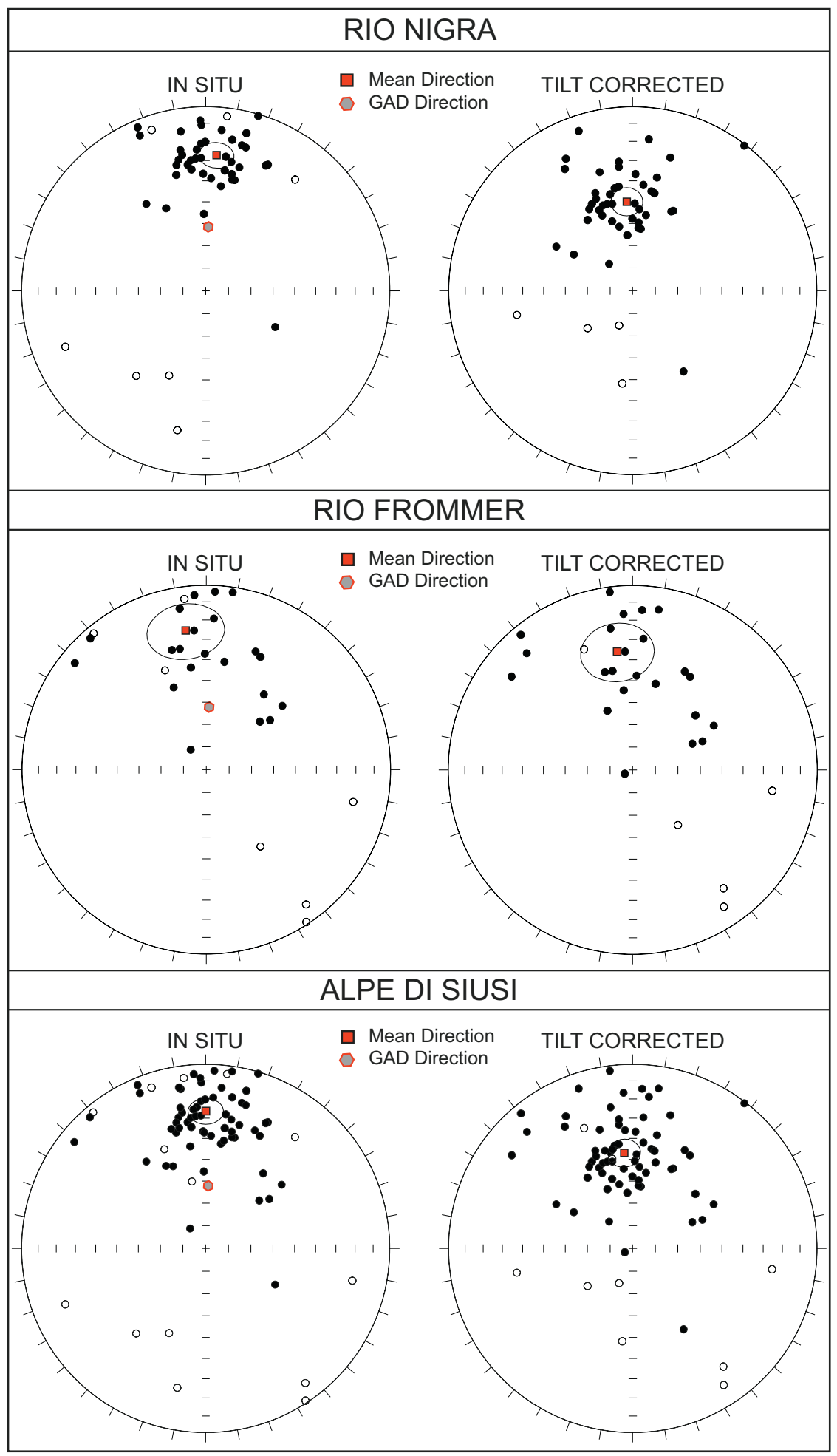

Fig. 9. Stereographic projections in in situ and tilt-corrected coordinates of the sample ChRM component directions from Rio Nigra (upper panel), Rio Frommer (middle panel), and from both sections together as Alpe di Siusi (lower panel). Fisher site-mean directions (red square) and $\mathrm{a}_{95}$ confidence circles are reported in each projection. The position of the present-day Geocentric Axial Dipole (GAD) field is also reported.

Chaohu, we propose magnetozone ME3r (Meishan) as correlative to Ch1r (lower Chaohu) (Fig. 11). Using the cyclostratigraphy of Meishan and Chaohu (Li et al., 2016), calibrated with the U-Pb zircon dates from Meishan (Burgess et al., 2014), we estimate the age of the Induan/ Olenekian boundary at $\sim 249.7 \mathrm{Ma}(\sim 0.2 \mathrm{Myr}$ younger than in Li et al., 2016), and a consequent duration of the Induan of $\sim 2.2$ Myr (Fig. 11).

The magnetostratigraphy of the Olenekian is relatively well constrained by data from Guandao (Lehrmann et al., 2006) and upper Chaohu (Li et al., 2016) (Fig. 11). The Olenekian/Anisian boundary is placed at the FO of conodont Chiosella timorensis in reverse magnetozone GD2r at Guandao (Lehrmann et al., 2006) (Fig. 11). This datum was found also in correlative magneto-biostratigraphic sections at Deşli Caira in Romania (Gradinaru et al., 2007), Kçira in Albania (Muttoni et al., 1996a), and Chios in Greece (Muttoni et al., 1995) (Fig. 11). The 
Table 1

Paleomagnetic directions, poles and paleolatitudes of Rio Nigra and Rio Frommer sections.

Mean directions

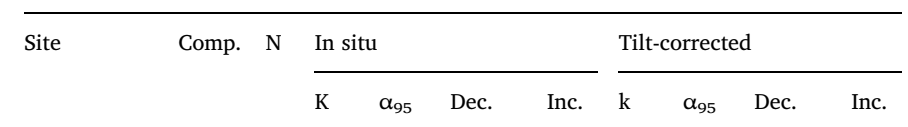

$\begin{array}{lllllllllll}\text { Rio Nigra } & \text { ChRM } & 47 & 10.8 & 6.6^{\circ} & 4.5^{\circ} \mathrm{E} & 27.1^{\circ} & 10.8 & 6.6^{\circ} & 356.1^{\circ} \mathrm{E} & 50.0^{\circ}\end{array}$

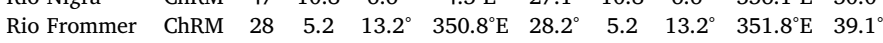

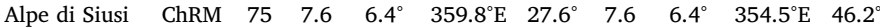

Geocentric axial dipole $2.6^{\circ} \mathrm{E} \quad 62.7^{\circ}$

Paleomagnetic poles and paleolatitudes

\begin{tabular}{llllll}
\hline Site & Lat. & Long. & $\mathrm{dp}$ & $\mathrm{dm}$ & Paleolatitude \\
\hline Rio Nigra & $74.0^{\circ} \mathrm{N}$ & $203.8^{\circ} \mathrm{E}$ & $5.9^{\circ}$ & $8.8^{\circ}$ & $30.8^{\circ} \mathrm{N} \pm 5^{\circ}$ \\
Rio Frommer & $64.7^{\circ} \mathrm{N}$ & $209.6^{\circ} \mathrm{E}$ & $9.4^{\circ}$ & $15.8^{\circ}$ & $22.1^{\circ} \mathrm{N} \pm 7^{\circ}$ \\
Alpe di Siusi & $70.5^{\circ} \mathrm{N}$ & $206.4^{\circ} \mathrm{E}$ & $5.3^{\circ}$ & $8.2^{\circ}$ & $27.5^{\circ} \mathrm{N} \pm 4^{\circ}$ \\
\hline
\end{tabular}

Note: Comp.: paleomagnetic component; N: number of samples; $k, \alpha_{95}$ : Fisher statistics parameters; Dec.: mean declination; Inc.: mean inclination; Lat.: latitude; Long.: longitude; dp, dm: confidence limits on poles.

middle part of the Guandao section, within GD2r, is provided also with $\mathrm{U}-\mathrm{Pb}$ zircon dates, from which an interpolated age of $247.28 \pm 0.12 \mathrm{Ma}$ for the Anisian base has been proposed (Lehrmann et al., 2015) (Fig. 11). Using $405 \mathrm{kyr}$ and $100 \mathrm{kyr}$ eccentricity cycles recognized in this mid-upper part of the Guandao section (the lower part of the section did not yield cyclostratigraphy), integrated with cycles recognized in the Germanic Basin sequence (Szurlies, 2007) as well as at the lower Chaohu and Meishan sections (Li et al., 2016), Li et al. (2018) estimated an age of 246.8 Ma for the base of the Anisian. This modest discrepancy between radiometric and astrochronologic estimates, on the order of $\sim 0.5 \mathrm{Myr}$, could be due to a missing $405 \mathrm{kyr}$ beat or radiometric dating errors (Li et al., 2016). Here, we adopt the age of 247.3 Ma for the Anisian base (Lehrmann et al., 2015), which leads to a $\sim 2.4$ Myr-long Olenekian and a $\sim 4.6$ Myr-long Early Triassic (Induan and Olenekian).

In summary, we adopted as reference sections to construct our Early Triassic GPTS the Meishan magnetostratigraphic section (Li and Wang, 1989), provided with a U-Pb zircon age estimate of $251.90 \pm 0.02 \mathrm{Ma}$ (Burgess et al., 2014) for the Permian/Triassic (Changhsingian/Induan) boundary as defined by the FO of $H$. parvus (Yin et al., 2001), the lower Chaohu section (Sun et al., 2009), and the entire Guandao magnetostratigraphic section (from magnetozone GDL1 to GDL6 [Lehrmann et al., 2006] and from GD1 to GD10 [Li et al., 2018]). The Induan/ Olenekian boundary, placed in the lower Chaohu section at the FO of $N$. waageni and cyclostratigraphically constrained to lie around $249.7 \mathrm{Ma}$, has been traced onto the Guandao reference section using magnetostratigraphy (Fig. 11). The Guandao section is provided also with direct evidence for the Olenekian/Anisian boundary (FO of Ch. timorensis) attached to an interpolated U-Pb age of $\sim 247.3 \mathrm{Ma}$ (Lehrmann et al., 2006, 2015), in substantial agreement with astrochronology (Li et al., 2018). Finally, we also adopted in our GPTS two short normal polarity magnetozones from Kçira (Kç1r.1n and Kç1r.2n) around the Olenekian-Anisian boundary (Muttoni et al., 1996a) that seem absent or poorly defined at Guandao (Fig. 11).

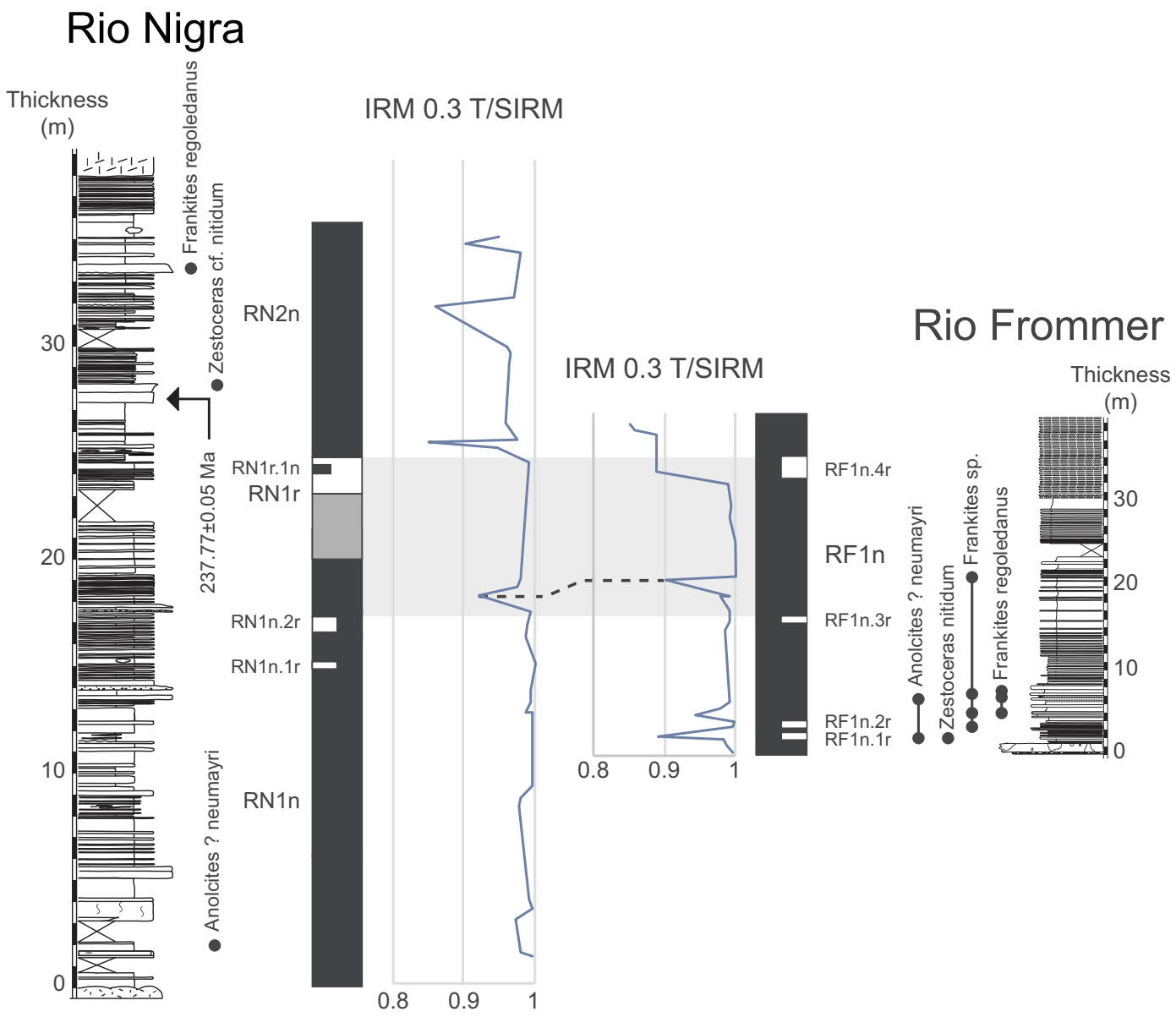

Fig. 10. Correlation between Rio Nigra and Rio Frommer based on magnetostratigraphy and the IRM $0.3 \mathrm{~T} / \mathrm{SIRM}$ ratio. Ammonoid biostratigraphy confirms that the two sections are broadly coeval. The $237.77 \pm 0.05 \mathrm{Ma} \mathrm{U}-\mathrm{Pb}$ detrital zircon age of Mietto et al. (2012) is also indicated. 


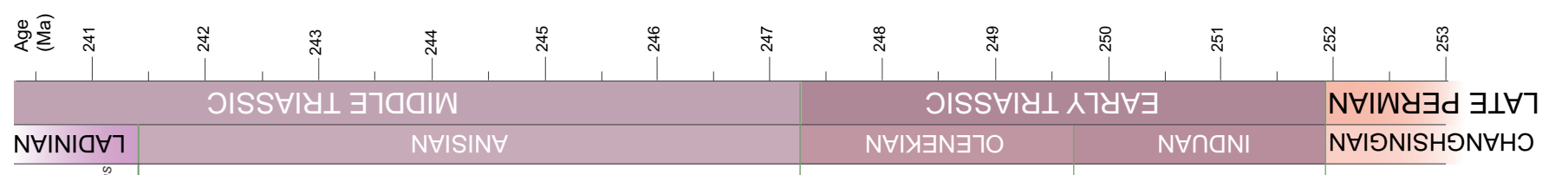

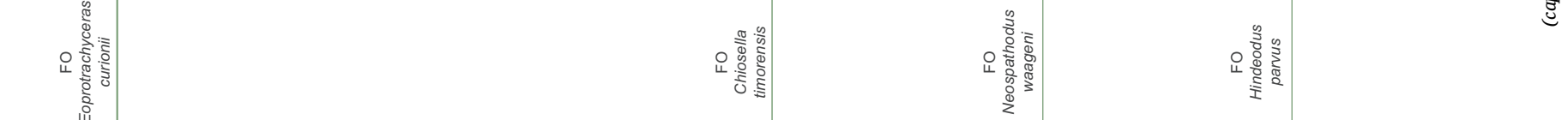

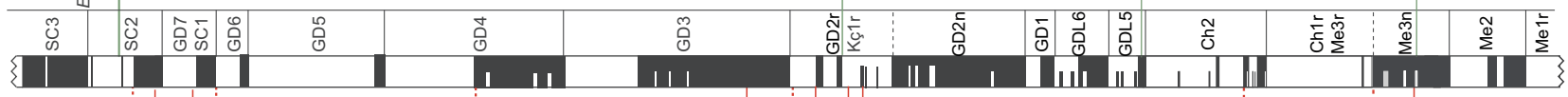

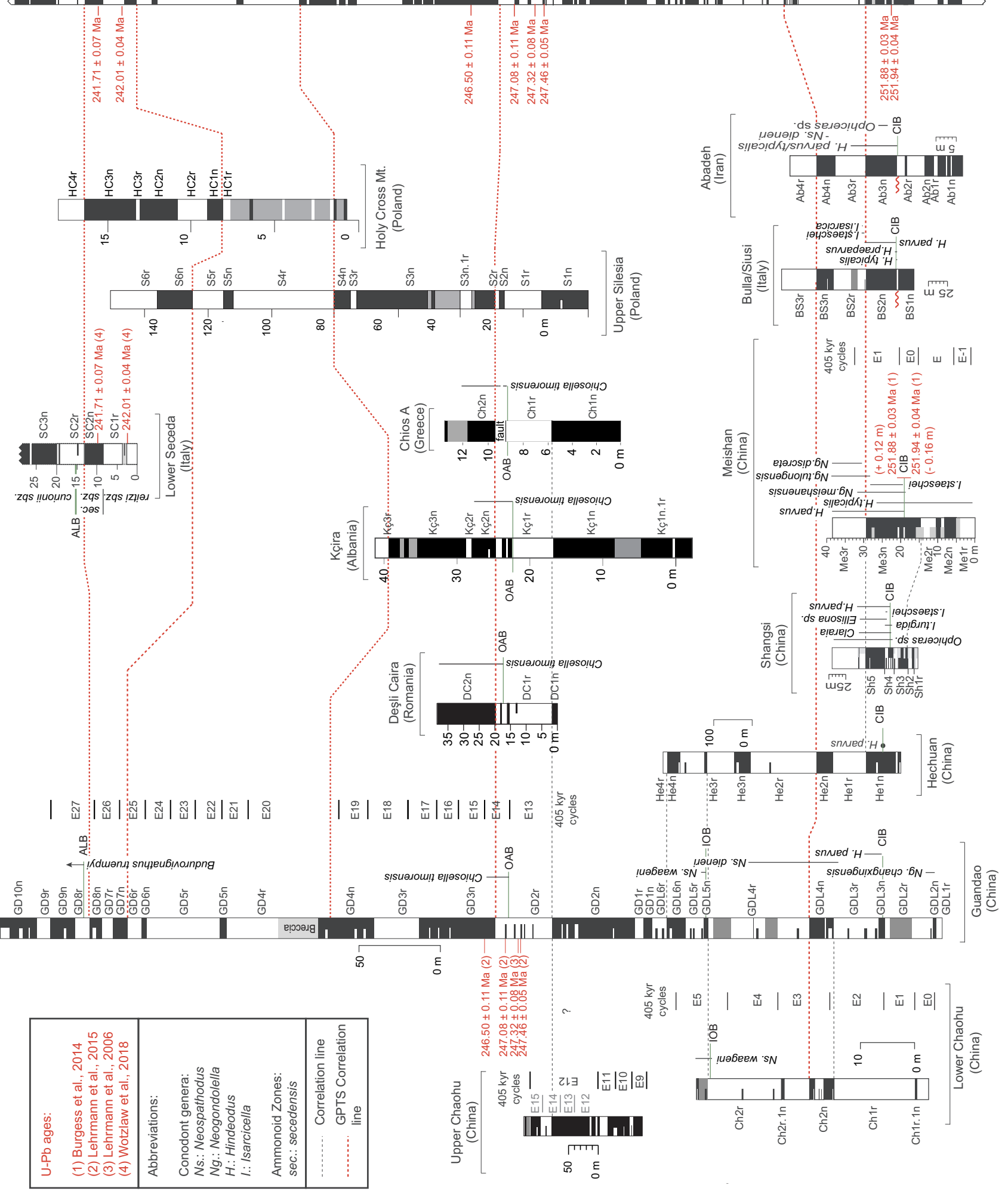




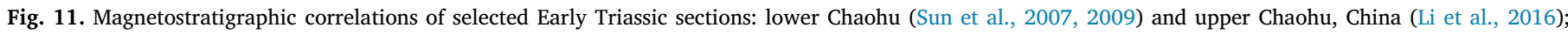

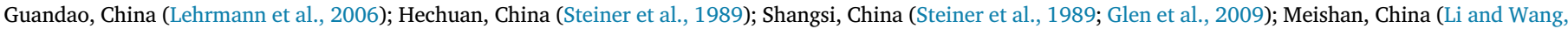

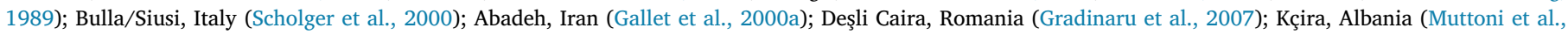

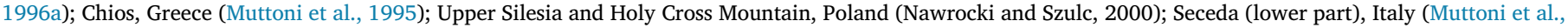

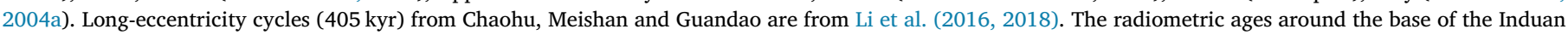

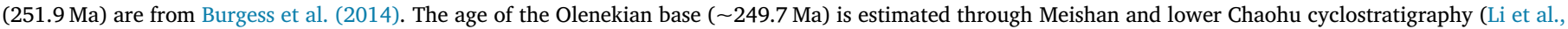

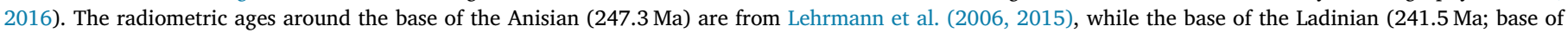

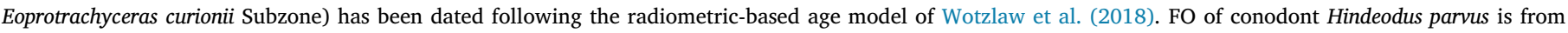

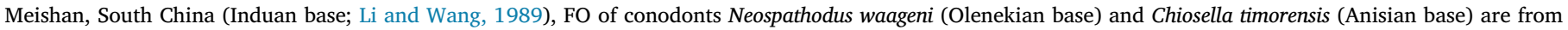

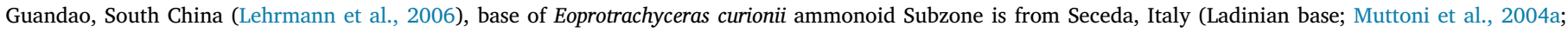

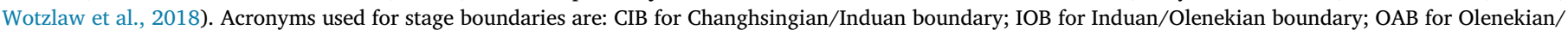
Anisian boundary; ALB for Anisian/Ladinian boundary.

\subsection{Middle Triassic (Anisian-Ladinian)}

At the Guandao reference section, the Anisian base (247.3 Ma, FO of C. timorensis; see above) is characterized by an interval of dominant normal polarity followed by an interval of mainly reverse polarity (Fig. 12). The Anisian/Ladinian boundary is placed at the FO of ammonoid Eoprotrachyceras curionii at the Bagolino GSSP in Italy (Brack et al., 2005) from a level that was litho-biostratigraphically correlated to reverse polarity magnetozone SC2r at Seceda in Italy (Muttoni et al., 2004a) where it was recently attributed an interpolated U-Pb age of $241.46 \pm 0.28 \mathrm{Ma}$ (Wotzlaw et al., 2018) (Fig. 12). At additional magneto-biostratigraphic sections, namely Pedraces in Italy (Brack and Muttoni, 2000), Frötschbach in Italy (Muttoni et al., 1996b, 1997), Belvedere in Italy (Brack and Muttoni, 2000), Aghia Triada in Greece (Muttoni et al., 1998), and Gammstein-1 in Austria (Gallet et al., 1998), the Anisian/Ladinian boundary is proxied by the FO of conodont Neogondolella praehungarica (Fig. 12). At Guandao, the Anisian/Ladinian boundary as approximated by the FO of Budurovignathus truempyi was attributed an astrochronological age of $241.5 \mathrm{Ma}$ by counting long and short eccentricity cycles from the Meishan GSSP at 251.9 Ma (Li et al., 2018; see also discussion above), in excellent agreement with Wotzlaw et al. (2018). Adopting the age of $241.46 \mathrm{Ma}$ for the Ladinian base (Wotzlaw et al., 2018), the Anisian Stage should be $\sim 5.8$ Myr-long (Fig. 12).

Additional U-Pb detrital zircon dates for the Anisian-Ladinian come from the Latemar carbonate platform of the Dolomites, Italy $(241.7+1.5 /-0.7 \mathrm{Ma}, \quad 241.2+0.7 /-0.6 \mathrm{Ma}, \quad 242.6 \pm 0.7 \mathrm{Ma}$; Mundil et al., 2003). Kent et al. (2004) used these ages in conjunction with magnetostratigraphic correlation of the Latemar sequence to Seceda magnetozone SC2 to infer a much faster tempo of platform carbonates deposition than originally proposed by Preto et al. (2001, 2004), who interpreted the $\sim 600$ shallowing-upward meter-scale cycles at Latemar as a $\sim 9-12 \mathrm{Myr}$ record of precessional forcing $(\sim 50 \mathrm{~m} / \mathrm{Myr}$ sediment accumulation rate) in sharp disagreement with the $\sim 2.2 \mathrm{Myr}$ duration predicted from the U-Pb ages and even shorter based on the presence of only one ammonoid zone, sub-Milankovitch cyclicity, and barely more than one magnetozone in the entire Latemar sequence (Mundil et al., 2003; Zühlke et al., 2003; Kent et al., 2004). Subsequent analyses of Latemar cyclostratigraphy (Meyers, 2008) favor very fast $(\sim 500 \mathrm{~m} / \mathrm{Myr})$ accumulation rates for the Latemar limestones, consistent with the $\mathrm{U}-\mathrm{Pb}$ dates and magnetobiostratigraphic constraints and with the recent magnetostratigraphy of the corresponding basinal Buchenstein beds in Rio Sacuz (Spahn et al., 2013).

Additional age constraints for the Anisian and Ladinian Stages are presented in Storck et al. (2018), providing new U-Pb zircon dates from the Bagolino section $(238.64 \pm 0.04 \mathrm{Ma}, 242.65 \pm 0.04 \mathrm{Ma})$, which are in agreement with the dates from Seceda (Wotzlaw et al., 2018). Moreover, new Ladinian U-Pb zircon dates are reported by (Storck et al., 2018) from the western Dolomites from a bentonite layer within the Wengen Formation in the Punta Grohmann section $(237.58 \pm 0.04 \mathrm{Ma} ; 237.68 \pm 0.04 \mathrm{Ma})$, and from the Monzoni $(238.14 \pm 0.05 \mathrm{Ma} ; \quad 238.19 \pm 0.05 \mathrm{Ma}) \quad$ and Predazzo $(238.08 \pm 0.09 \mathrm{Ma})$ magmatic intrusions and dykes. The U-Pb dates from Punta Grohmann are coherent with the U-Pb date from Rio Nigra (Mietto et al., 2012), as confirmed by lithostratigraphic correlations between Alpe di Siusi and Punta Grohmann (Storck et al., 2018). These new radiometric ages constrain Middle Triassic magmatism in the Dolomites to a $\sim 5 \mathrm{Myr}$ long interval, including a $\sim 0.9 \mathrm{Myr}$ episode of basaltic volcanism during the Ladinian (Storck et al., 2018).

The magnetostratigraphy of the Ladinian is well represented at Seceda in Italy (Muttoni et al., 2004a), Mayerling in Austria (Gallet et al., 1994, 1998) and Prati di Stuores in Italy (Broglio Loriga et al., 1999; Mietto et al., 2012), which are chosen as reference sections for our composite GPTS (Fig. 12). The Ladinian/Carnian (Middle/Late Triassic) boundary is placed at the Prati di Stuores GSSP at the FO of ammonoid Daxatina canadensis and is approximated by the FO of conodont Paragondolella polygnathiformis (Mietto et al., 2012). The boundary falls toward the base of normal polarity magnetozone S2n (Broglio Loriga et al., 1999; Mietto et al., 2012) (Fig. 12). The Prati di Stuores magnetostratigraphy (Broglio Loriga et al., 1999) was originally correlated to the Mayerling magnetostratigraphy (Gallet et al., 1998) across magnetozones MA3n-MA5n (Broglio Loriga et al., 1999; Hounslow and Muttoni, 2010). After the finding of $P$. polygnathiformis at Prati di Stuores (Mietto et al., 2012), Kent et al. (2017) proposed a correlation of Prati di Stuores to MA5n-MA5r at Mayerling that optimizes the general distribution of $P$. polygnathiformis in both sections (Fig. 12). According to this revised correlation, the FO of $P$. polygnathiformis at Mayerling should fall slightly below the FO of D. canadensis at Prati di Stuores, a situation that has been reported also in other sections such as Guling and Muth in the Spiti Valley of India (Bhargava et al., 2004; Krystyn et al., 2004).

A comparison of the conodont and ammonoid biostratigraphic scales from the Reifling Basin of Austria, to which Mayerling belongs, and the Dolomites (Krystyn, 1983; Mietto and Manfrin, 1995; Gallet et al., 1998; Hochuli et al., 2015), leads us to infer that the neumayri-regoledanus Subzones interval recorded at Rio Nigra and Rio Frommer (see also above) should broadly fall in the mid part of the Mayerling section. Thus, reverse magnetozone RN1r at Rio Nigra, closely associated with the $237.77 \pm 0.05 \mathrm{Ma}$ U-Pb zircon date, can be reasonably correlated to MA3r at Mayerling (Fig. 12). Through the U-Pb zircon dates of Seceda (Wotzlaw et al., 2018) and Rio Nigra (Mietto et al., 2012), the base of the Carnian Stage can be approximated at $\sim 236.8 \mathrm{Ma}$, in agreement with the age proposed by Mietto et al. (2012), leading to a duration of $\sim 4.6 \mathrm{Myr}$ for the Ladinian and a $\sim 10.5 \mathrm{Myr}-$ long Middle Triassic (Anisian and Ladinian) (Fig. 12).

In summary, we adopted as reference sections to construct our Anisian-Ladinian GPTS the U-Pb-calibrated (Wotzlaw et al., 2018) Seceda magneto-biostratigraphic sequence (Muttoni et al., 2004a) where the Anisian/Ladinian boundary is traced at the FO of $E$. curionii with an interpolated $\mathrm{U}-\mathrm{Pb}$ age of $241.46 \pm 0.28 \mathrm{Ma}$, and the Mayerling magneto-biostratigraphic sequence straddling the conodont Ladinian/Carnian boundary interval. We traced magnetostratigraphically onto Mayerling the Ladinian/Carnian boundary as defined by the FO of ammonoid D. canadensis at the Prati di Stuores GSSP (Mietto et al., 2012). The Ladinian is further constrained by the U-Pb zircon date of $237.77 \pm 0.05 \mathrm{Ma}$ from Rio Nigra (Mietto et al., 2012; this study). 


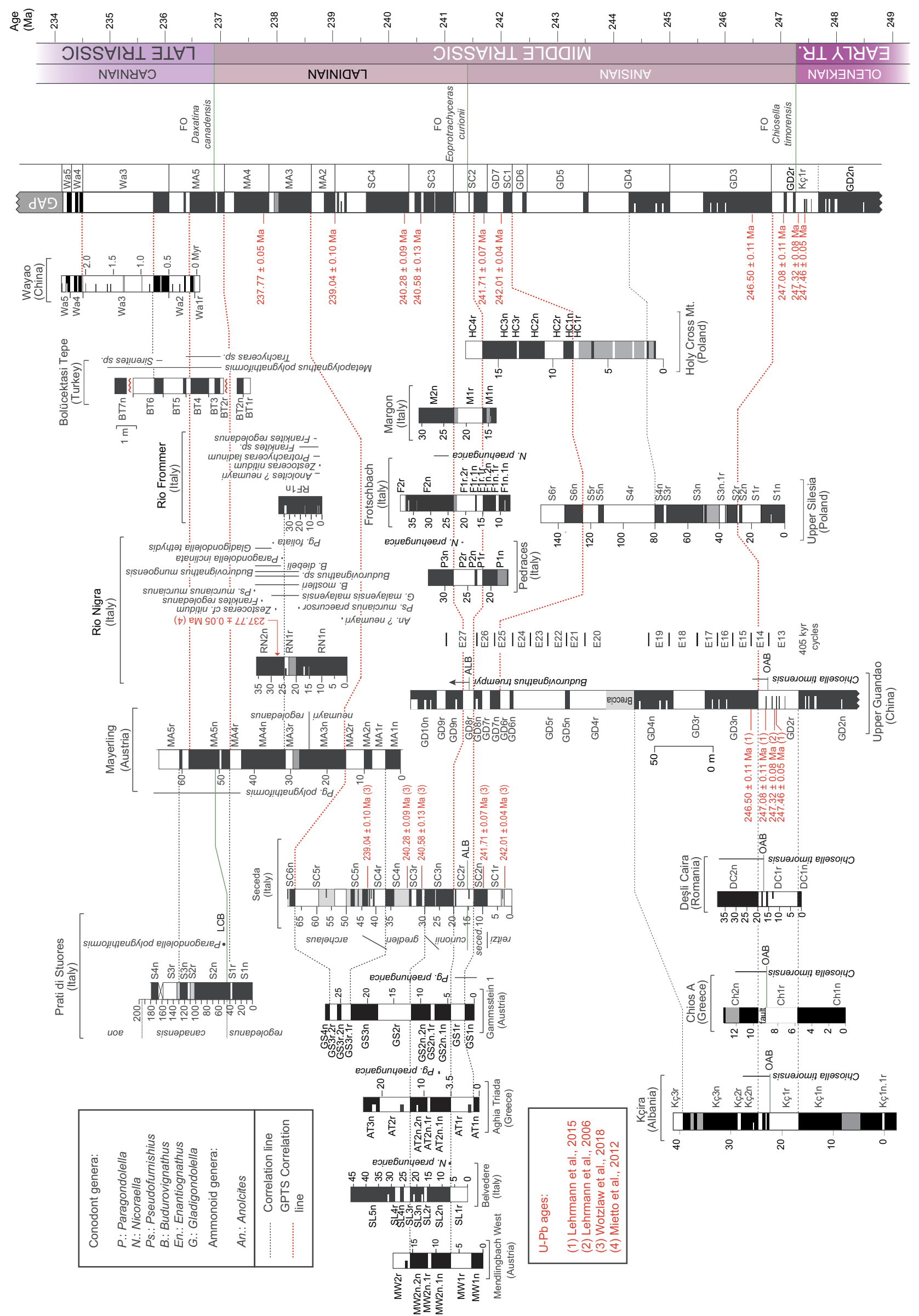




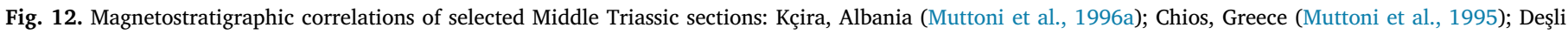

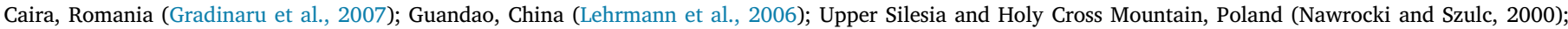

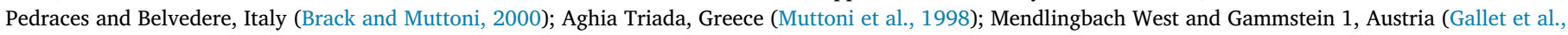

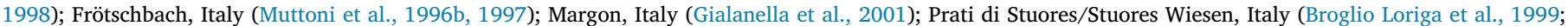

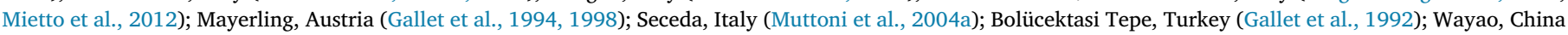

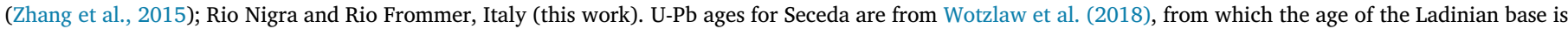

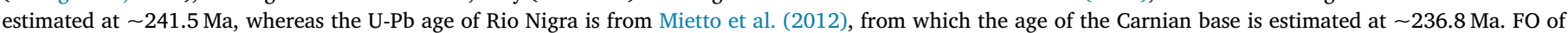

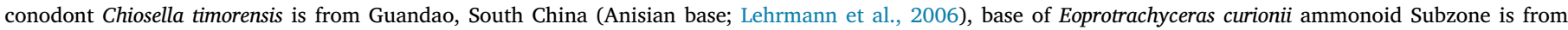

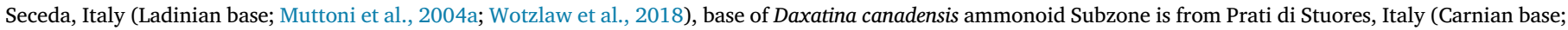

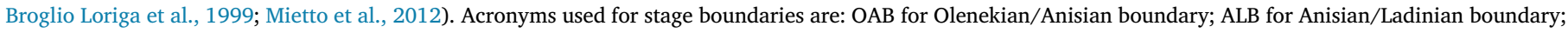
LCB for Ladinian/Carnian boundary.

\subsection{Late Triassic (Carnian-Norian-Rhaetian)}

The magnetostratigraphy of the early part of the Carnian (Julian) is represented by marine sections at Prati di Stuores (Broglio Loriga et al., 1999; Mietto et al., 2012), Mayerling (Gallet et al., 1994, 1998), and Bolücektasi Tepe in Turkey (Gallet et al., 1992), as well as the astronomically-tuned (100 and $405 \mathrm{kyr}$ eccentricity cycles) $\sim 2.4$ Myr-long Wayao composite section from China (Zhang et al., 2015) (Fig. 13).

The Wayao section, comprised of the Zhuganpo Member (Falang Formation) overlain by the Xiaowa Member (Falang Fm.), has a complex biostratigraphic attribution based on apparently contradictory conodont and ammonoid associations (e.g., Zhang et al., 2015 and references therein; Zou et al., 2015). In brief, the section is considered Carnian in age essentially based on the presence of conodonts Paragondolella polygnathiformis (=Metapolygnathus polygnathiformis) throughout the Zhuganpo $\mathrm{Mb}$. and Hayashiella nodosa ( $=$ M. nodosus) in its uppermost beds (Zhang et al., 2015 and references therein), in association with polygnathiformis-nodosa transitional forms (Zou et al., 2015). The FO of $P$. polygnathiformis is closely associated with the base of the Carnian at the Prati di Stuores GSSP (Broglio Loriga et al., 1999; Mietto et al., 2012; see above), while $H$. nodosa first occurs shortly afterwards still in the Carnian (e.g., Aghia Marina section; Muttoni et al., 2014). Zou et al. (2015) reported ammonoids from the Zhuganpo $\mathrm{Mb}$. that are largely endemic and of little chronological value, except for a Trachyceras assemblage in the upper part of the formation that they attributed to the Carnian, whose base is indeed placed at the base of the Trachyceras Zone at the Prati di Stuores GSSP (Mietto et al., 2012). In spite of this relatively clear indication of Carnian age for the Zhuganpo Mb., Zou et al. (2015) tentatively attributed the pre-Trachyceras endemic ammonoid association to the Ladinian and placed the Ladinian/Carnian boundary in the upper part of the Zhuganpo Mb. We consider the arguments presented in Zou et al. (2015) in support of a Ladinian age of the Zhuganpo $\mathrm{Mb}$. as insufficient and maintain a Carnian age for the formation and consequently for the Wayao composite section as originally proposed by Zhang et al. (2015). Following these considerations, the magnetostratigraphy of the $\sim 2.4$ Myr-long Wayao composite section is tentatively correlated to the upper part of the Carnian Bolücektasi Tepe section (Fig. 13).

The remainder of the Late Triassic timescale is mostly represented by the continental Newark APTS (e.g. Kent et al., 1995; Kent and Olsen, 1999; Olsen and Kent, 1999; Olsen et al., 2011; Olsen et al., 2015; Kent et al., 2017) anchored to a U-Pb zircon age of $201.52 \pm 0.03$ Ma for the base of the Central Atlantic Magmatic Province (CAMP) basalts (Blackburn et al., 2013), and altogether extending from $\sim 232 \mathrm{Ma}$ to $\sim 199 \mathrm{Ma}$ in the Early Jurassic (Kent et al., 2017) (Fig. 13). The Newark astrochronology was recently confirmed by results from the Petrified Forest drill core project, where the U-Pb detrital zircon dates from core PFNP-1A (210.08 $\pm 0.22 \mathrm{Ma}, 212.81 \pm 1.25 \mathrm{Ma}, 213.55 \pm 0.28 \mathrm{Ma}$, $214.08 \pm 0.20 \mathrm{Ma}$; Fig. 13) have been linked to the Newark-APTS through magnetostratigraphy (Kent et al., 2018). Moreover, the study demonstrated the stability of the 405 kyr eccentricity cycle, which was used as a framework for the Newark APTS.

As a further confirmation of the Newark chronology, the U-Pb zircon date of $230.91 \pm 0.33 \mathrm{Ma}$ of Furin et al. (2006) from the
Carnian conodont-bearing Pignola-2 section of Italy (Rigo et al., 2007, 2012) was magnetostratigraphically correlated to Newark magnetozone E3 at $\sim 231 \mathrm{Ma}$ (Maron et al., 2017) (Fig. 13). The Carnian/Norian boundary, currently placed at the Pizzo Mondello section in Sicily in an interval between the FOs of conodonts Metapolygnathus parvus and Carnepigondolella gulloae (Mazza et al., 2010, 2012a; Onoue et al., 2018; Rigo et al., 2018) within Pizzo Mondello magnetozone PM4r (Muttoni et al., 2004b), was magnetostratigraphically traced to Newark magnetozone E7r at $\sim 227 \mathrm{Ma}$ (Krystyn et al., 2002; Muttoni et al., 2004b; Kent et al., 2017) (Fig. 13). Similar results were obtained also by Channell et al. (2003) at the Silická Brezová section in Slovakia. Thus, using an age of $\sim 236.8 \mathrm{Ma}$ for the Ladinian/Carnian boundary (see below) and $\sim 227 \mathrm{Ma}$ for the Carnian/Norian boundary, we obtain a 2.8 Myr duration for the Carnian Stage (Fig. 13). The Carnian magnetostratigraphic record is probably incomplete as there is currently no reliable way to correlate or append the Wayao and Bolücektasi Tepe magnetostratigraphies to the Newark-APTS or Pignola-2 section (Fig. 13; see also Kent et al., 2017). Awaiting further investigation, a $\sim 2$ Myr gap is provisionally inserted between these two blocks of data (Fig. 13). This gap may straddle the Carnian Pluvial Episode, a distinct sedimentary episode particularly evident in the Dolomites (Bernardi et al., 2018 and references therein).

The Norian/Rhaetian boundary was dated through magnetostratigraphic correlation of the Pignola-Abriola section from Italy (Maron et al., 2015), candidate GSSP for the Rhaetian Stage (Rigo et al., 2016; Bertinelli et al., 2016), to the Newark APTS. At Pignola-Abriola, the boundary is approximated by the FO of conodont Misikella posthernsteini sensu stricto within reverse magnetozone MPA5r (Maron et al., 2015). This level was magnetostratigraphically traced to Newark magnetozone E20r dated to $\sim 205.7 \mathrm{Ma}$ (Maron et al., 2015) (Fig. 13). This age is coherent with the U-Pb age estimate of Wotzlaw et al. (2014) for a level close to the last occurrence of the Norian bivalve Monotis subcircularis at the Levanto section in Peru (205.50 $\pm 0.35 \mathrm{Ma})$. The Norian/Rhaetian boundary at Pignola-Abriola is also approximated by a negative $\delta^{13} \mathrm{C}_{\text {org }}$ excursion (Maron et al., 2015; Rigo et al., 2016; Bertinelli et al., 2016) that seems to be present in other marine sections (Zaffani et al., 2017). Previously, the Norian/Rhaetian boundary was placed in the Steinbergkogel section, GSSP candidate for the Rhaetian Stage, at the FO of M. posthernsteini sensu latu, and was magnetostratigraphically correlated to Newark levels at around 209 Ma (Krystyn et al., 2007a,b). M. posthernsteini sensu latu was later reinterpreted as a Misikella hernsteini/ posthernsteini transitional form (Maron et al., 2015; Rigo et al., 2016, 2018; Bertinelli et al., 2016), following the new taxonomical definition of Giordano et al. (2010), from which was derived a recalibration of the Norian/Rhaetian boundary at the FO M. posthernsteini sensu strictu at $\sim 205.7 \mathrm{Ma}$ as described above.

The Triassic/Jurassic boundary as approximated by the FO of ammonoid Psiloceras spelae in the Levanto section (Peru) has been recently assigned an age of $201.36 \pm 0.17 \mathrm{Ma}$ (Wotzlaw et al., 2014) through the recalibration of previous U-Pb dates (Schoene et al., 2010; Guex et al., 2012), falling in the basal part of magnetozone E24n in the Newark-Hartford APTS (Fig. 13). The carbon isotope excursions close to the Triassic/Jurassic boundary (Precursor, Initial and Main CIE), commonly related to the onset of the Central Atlantic Magmatic Province 
要毭

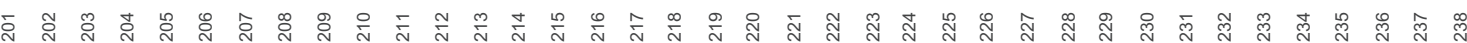

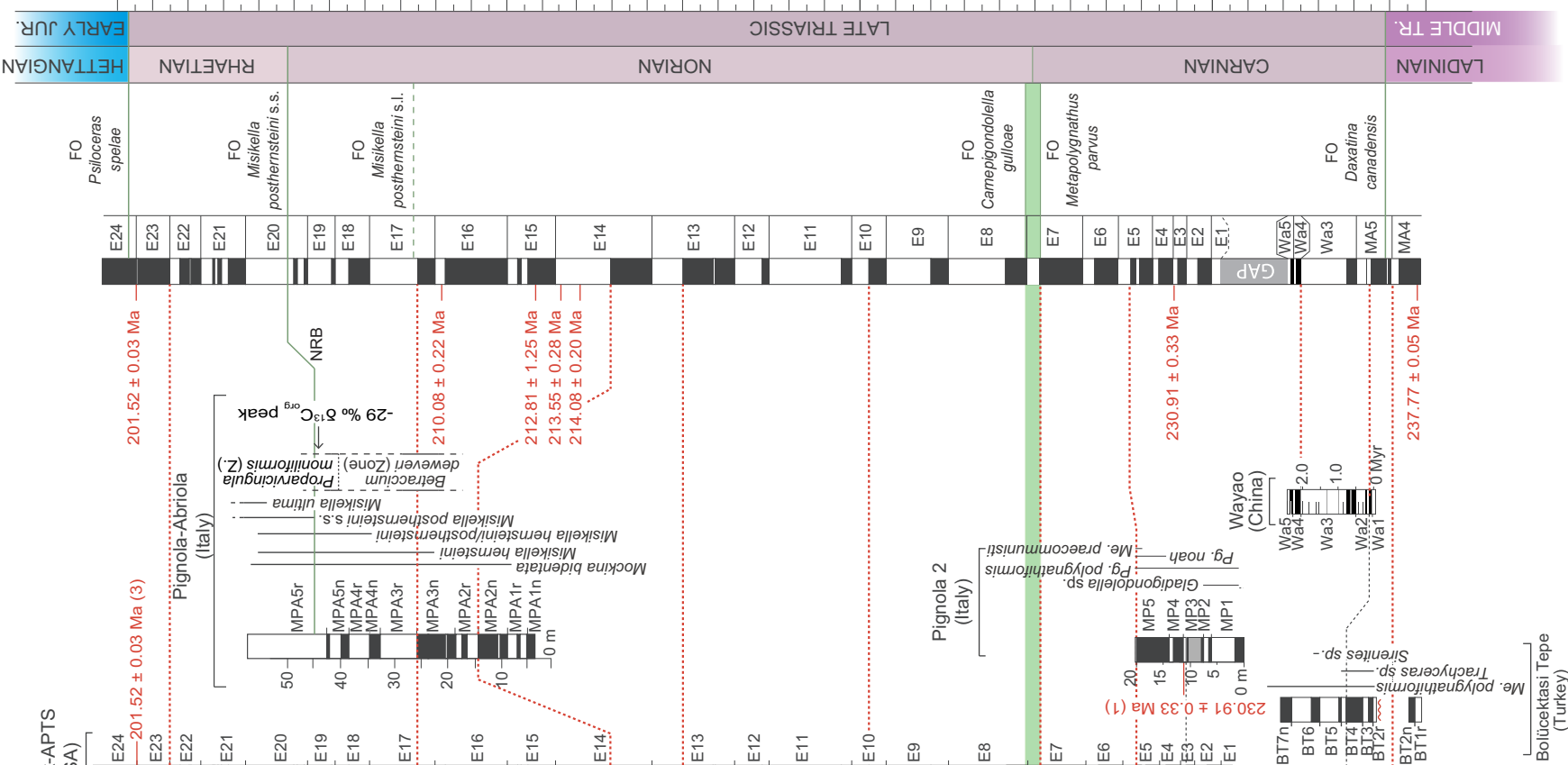

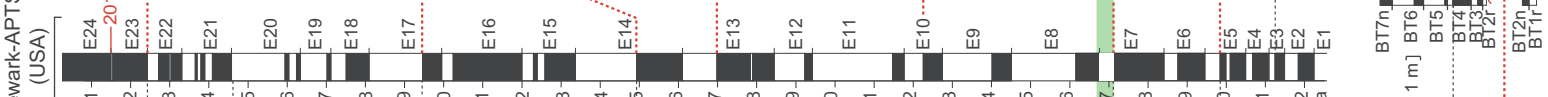

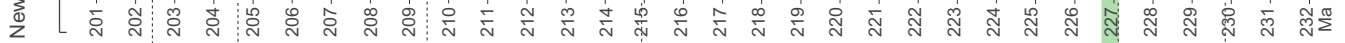
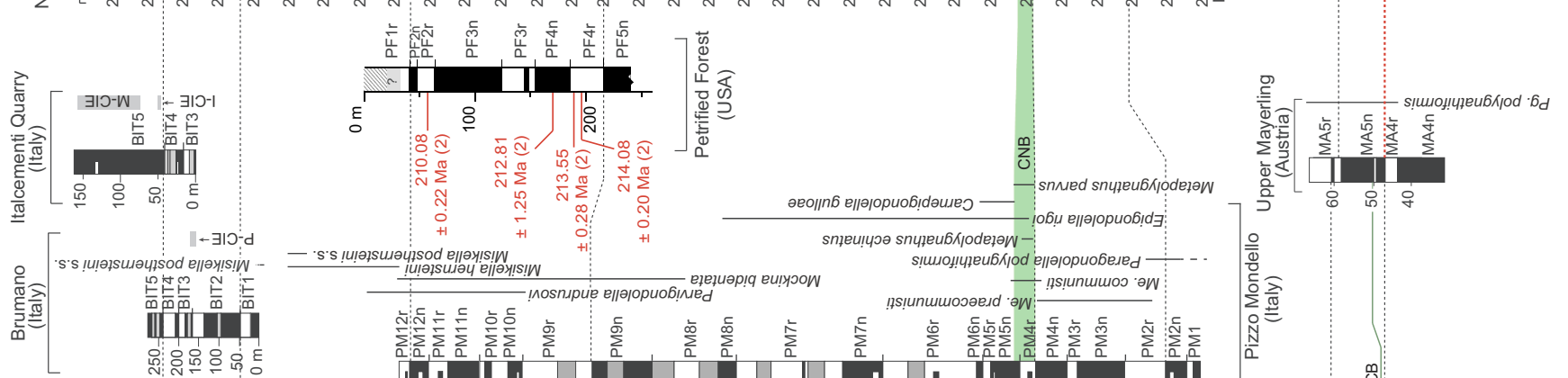

용ㅇㅇㅇㅇㅇㅡ

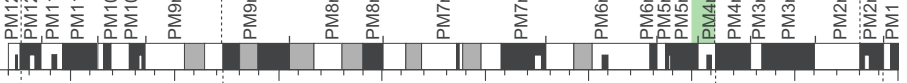

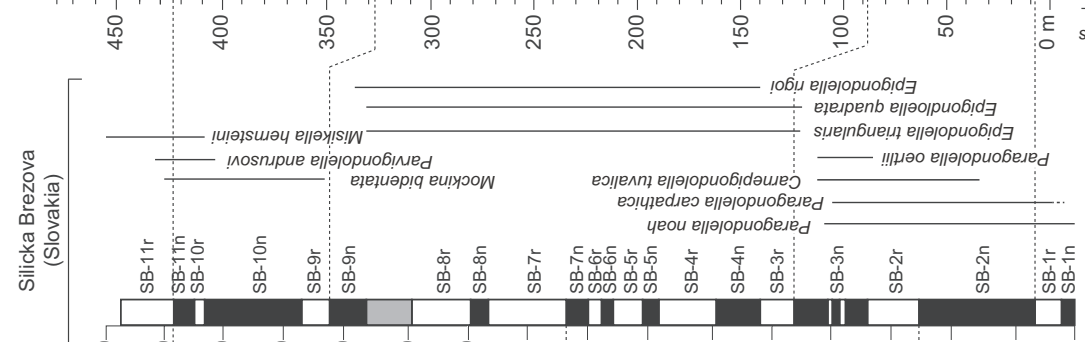

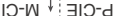
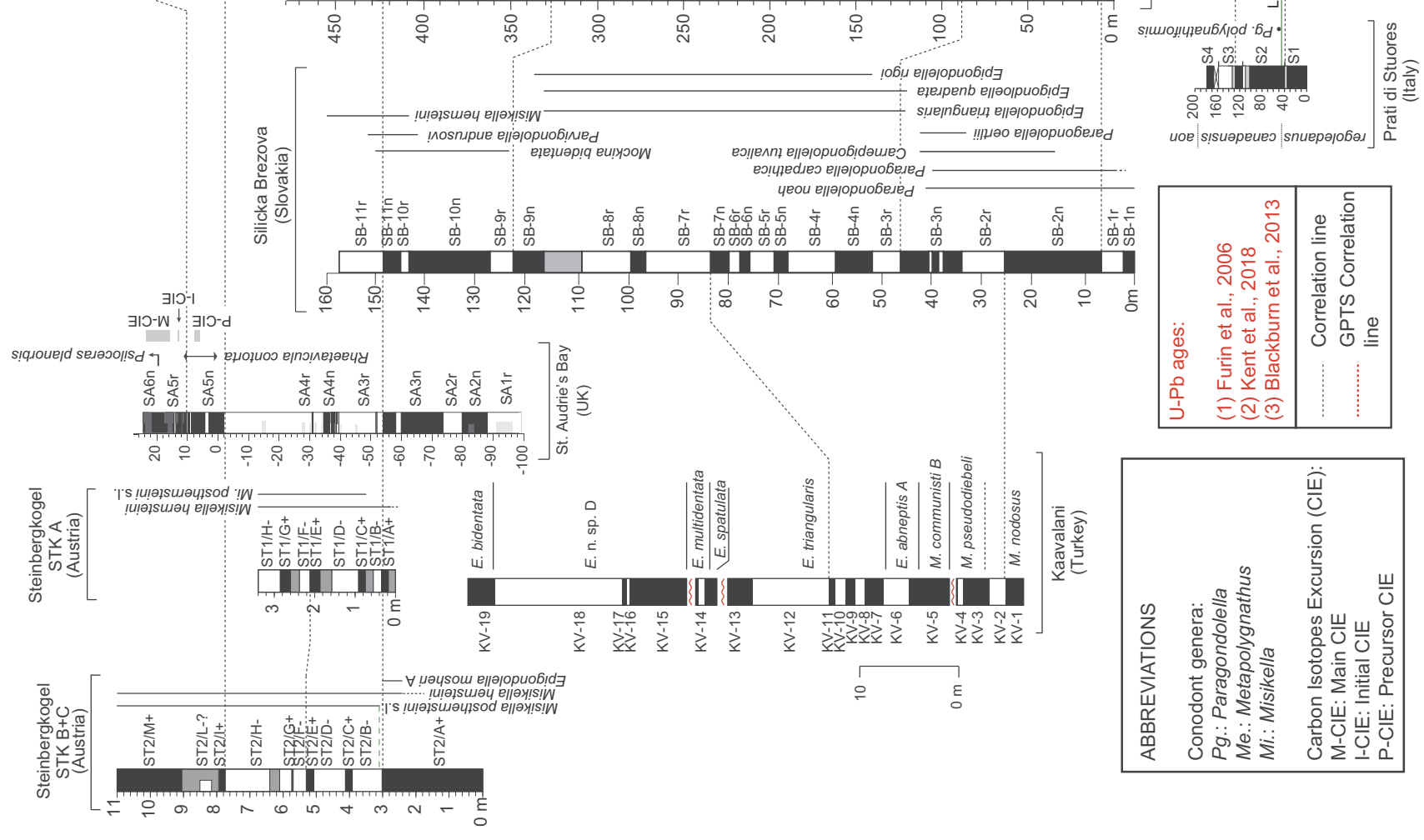


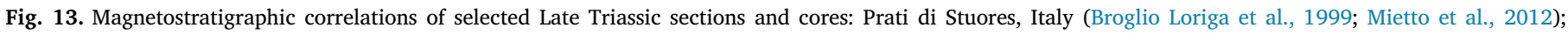

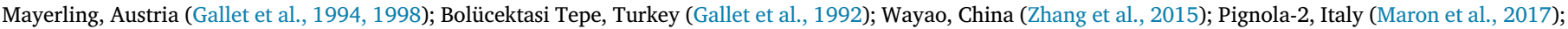

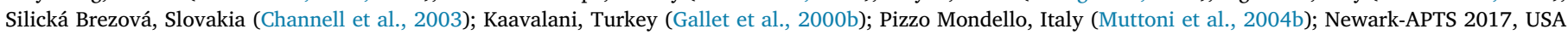

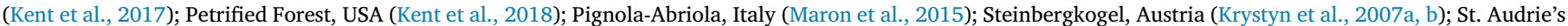

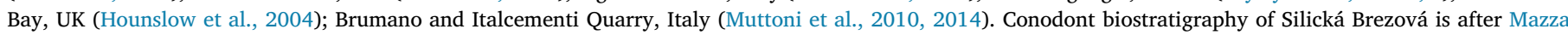

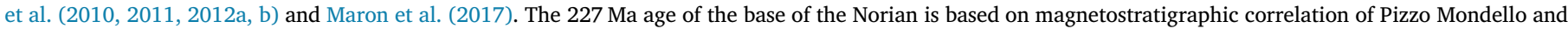

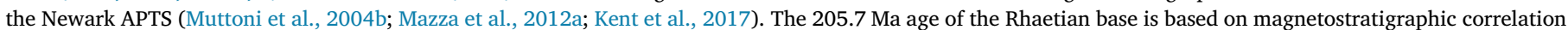

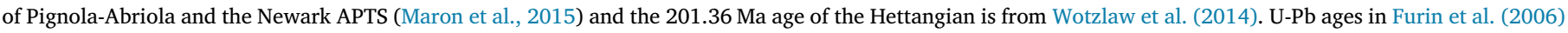

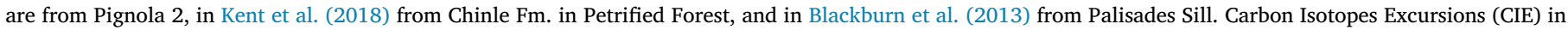

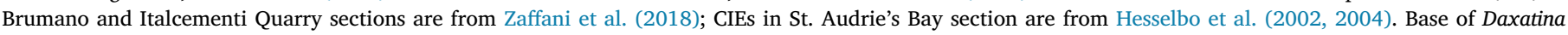

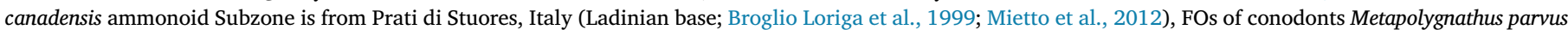

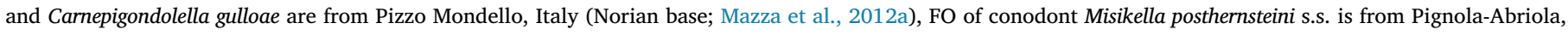

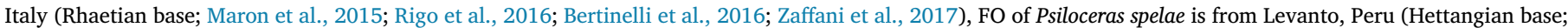

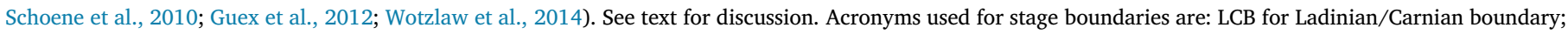
CNB for Carnian/Norian boundary; NRB for Norian/Rhaetian boundary.

(e.g. Marzoli et al., 2004; Hesselbo et al., 2007; Deenen et al., 2010; Dal Corso et al., 2014; Davies et al., 2017) and associated with the endTriassic extinction event (e.g. Hesselbo et al., 2002; Guex et al., 2004; Ward et al., 2004; Richoz et al., 2007; Van de Schootbrugge et al., 2008; Tanner, 2010; Whiteside and Ward, 2011; Hillebrandt et al., 2013; Zaffani et al., 2017; Lucas and Tanner, 2018), are located in the murky SA5n.2n-SA6n magnetostratigraphic interval of the St. Audrie's Bay section (Hesselbo et al., 2002, 2004; Hounslow et al., 2004) and in the BIT2r-BIT5n interval of Brumano/Italcementi Quarry (Muttoni et al., 2010; Zaffani et al., 2018), which broadly correspond to the E22n-E24n interval in the Newark-APTS (Fig. 13).

In summary, we adopted as reference sections to construct our Late Triassic GPTS the astronomically tuned $\sim 2.4$ Myr-long Wayao composite magnetostratigraphy (Zhang et al., 2015) and the Newark APTS (Kent et al., 2017) provided at the base and in the mid-part with U-Pb zircon age constraints from Pignola-2 (Furin et al., 2006; Maron et al., 2017) and the Petrified Forest drill core (Kent et al., 2018), respectively. We traced magnetostratigraphically onto the Newark APTS at the $\sim 227 \mathrm{Ma}$ the level of the Carnian/Norian boundary as defined at Pizzo Mondello (Muttoni et al., 2004b) between the FOs of conodonts Metapolygnathus parvus and Carnepigondolella gulloae (Mazza et al., 2012a; Onoue et al., 2018; Rigo et al., 2018). We also traced onto the Newark-APTS at $\sim 205.7 \mathrm{Ma}$ the Norian/Rhaetian boundary as defined at Pignola-Abriola by the FO of conodont Misikella posthernsteini sensu stricto (Maron et al., 2015). With a Rhaetian base at 205.7 Ma, the Norian Stage is estimated to be $\sim 21.3 \mathrm{Myr}$ long. According to the Triassic/Jurassic boundary age of $201.36 \pm 0.17 \mathrm{Ma}$ (Wotzlaw et al., 2014), the duration of the Rhaetian is $\sim 4.3 \mathrm{Myr}$ and the duration of the Late Triassic (Carnian, Norian and Rhaetian) is $\sim 35.4 \mathrm{Myr}$.

\subsection{Summary and error estimates}

As described above and illustrated in Figs. 11-13, we selected key Tethyan marine magnetostratigraphic sections as "building blocks" for the construction of a GPTS that embraces the entire Triassic System from the Changsinghian/Induan (Permian/Triassic) boundary to the Rhaetian/Hettangian (Triassic/Jurassic) boundary for a total duration of $\sim 50.5 \mathrm{Myr}$ (Fig. 14; magnetozone ages and durations are in Supplemental Table S2). Reference sections have been selected among those deemed to have minimum variations in sediment accumulation rates (as reflected by lithological variations) and to be provided with $\mathrm{U}$ $\mathrm{Pb}$ age constraints (see Table 2 for a summary) and/or biostratigraphic datums useful to define stage boundaries. For the Late Triassic, we adopted the Newark APTS correlated to stage boundaries from Tethyan marine sections. We also opted to maintain in our composite GPTS the magnetozone nomenclature of the constituent reference sections (e.g.,

Table 2

Radiometric datings and Stage boundaries ages.

\begin{tabular}{|c|c|c|c|c|c|}
\hline Age (Ma) & Locality & Stage & Event & Magnetozone (GPTS) & Reference \\
\hline $251.902 \pm 0.024$ & Meishan (South China) & Induan & FO Hindeodus parvus; Changhsingian-Induan boundary & Me3n & Burgess et al., 2014 \\
\hline$\sim 249.7$ & Guandao (South China) & Olenekian & FO Neospathodus waageni; Induan-Olenekian boundary & GDL5n & This study \\
\hline $247.46 \pm 0.05$ & Guandao (South China) & Olenekian & & GD2r/Kç1r & Lehrmann et al., 2015 \\
\hline $247.32 \pm 0.08$ & Guandao (South China) & Olenekian & & GD2r/Kç1r & Lehrmann et al., 2006 \\
\hline $247.28 \pm 0.12$ & Guandao (South China) & Anisian & FO Chiosella timorensis; Olenekian-Anisian boundary & GD2r/Kç1r & Lehrmann et al., 2015 \\
\hline $247.08 \pm 0.11$ & Guandao (South China) & Anisian & & GD2r/Kç1r & Lehrmann et al., 2015 \\
\hline $246.50 \pm 0.11$ & Guandao (South China) & Anisian & & GD3n & Lehrmann et al., 2015 \\
\hline $242.010 \pm 0.040$ & Seceda (Italy) & Anisian & & GD7r/SC1r & Wotzlaw et al., 2018 \\
\hline $241.705 \pm 0.065$ & Seceda (Italy) & Anisian & & $\mathrm{SC} 2 \mathrm{n}$ & Wotzlaw et al., 2018 \\
\hline$\sim 241.4$ & Seceda (Italy) & Ladinian & FO Eoprotrachyceras curionii; Anisian-Ladinian boundary & $\mathrm{SC} 2 \mathrm{r}$ & $\begin{array}{l}\text { This study; Wotzlaw } \\
\text { et al., } 2018\end{array}$ \\
\hline $240.576 \pm 0.126$ & Seceda (Italy) & Ladinian & & SC3n & Wotzlaw et al., 2018 \\
\hline $240.285 \pm 0.095$ & Seceda (Italy) & Ladinian & & $\operatorname{SC} 4 \mathrm{n}$ & Wotzlaw et al., 2018 \\
\hline $239.044 \pm 0.104$ & Seceda (Italy) & Ladinian & & MA2n & Wotzlaw et al., 2018 \\
\hline $237.773 \pm 0.052$ & Rio Nigra (Italy) & Ladinian & & MA4n & Mietto et al., 2012 \\
\hline$\sim 236.8$ & Prati di Stuores (Italy) & Carnian & FO Daxatina cf. canadensis; Ladinian-Carnian boundary & MA5n & This study \\
\hline $230.91 \pm 0.33$ & Pignola 2 (Italy) & Carnian & & $\mathrm{E} 3 \mathrm{r}$ & Furin et al., 2006 \\
\hline$\sim 227$ & Pizzo Mondello (Italy) & Norian & $\begin{array}{l}\text { FO Metapolygnathus parvus; FO Carnepigondolella gulloae; } \\
\text { Carnian-Norian boundary }\end{array}$ & E8n & $\begin{array}{l}\text { Mazza et al., 2012a; } \\
\text { Onoue et al., } 2018\end{array}$ \\
\hline$\sim 207.5$ & Pignola-Abriola (Italy) & Rhaetian & FO Misikella posthernsteini s.s.; Norian-Rhaetian boundary & E20r & Maron et al., 2015 \\
\hline $214.08 \pm 0.20$ & Petrified Forest (USA) & Norian & & E14r & Kent et al., 2018 \\
\hline $213.55 \pm 0.28$ & Petrified Forest (USA) & Norian & & $\mathrm{E} 14 \mathrm{r}$ & Kent et al., 2018 \\
\hline $212.81 \pm 1.25$ & Petrified Forest (USA) & Norian & & E15n & Kent et al., 2018 \\
\hline $210.08 \pm 0.22$ & Petrified Forest (USA) & Norian & & E16r & Kent et al., 2018 \\
\hline $201.520 \pm 0.034$ & Newark Basin (USA) & Rhaetian & Palisades sill - Central Atlantic Magmatic Province (CAMP) & $\mathrm{E} 24 \mathrm{n}$ & Blackburn et al., 2013 \\
\hline
\end{tabular}




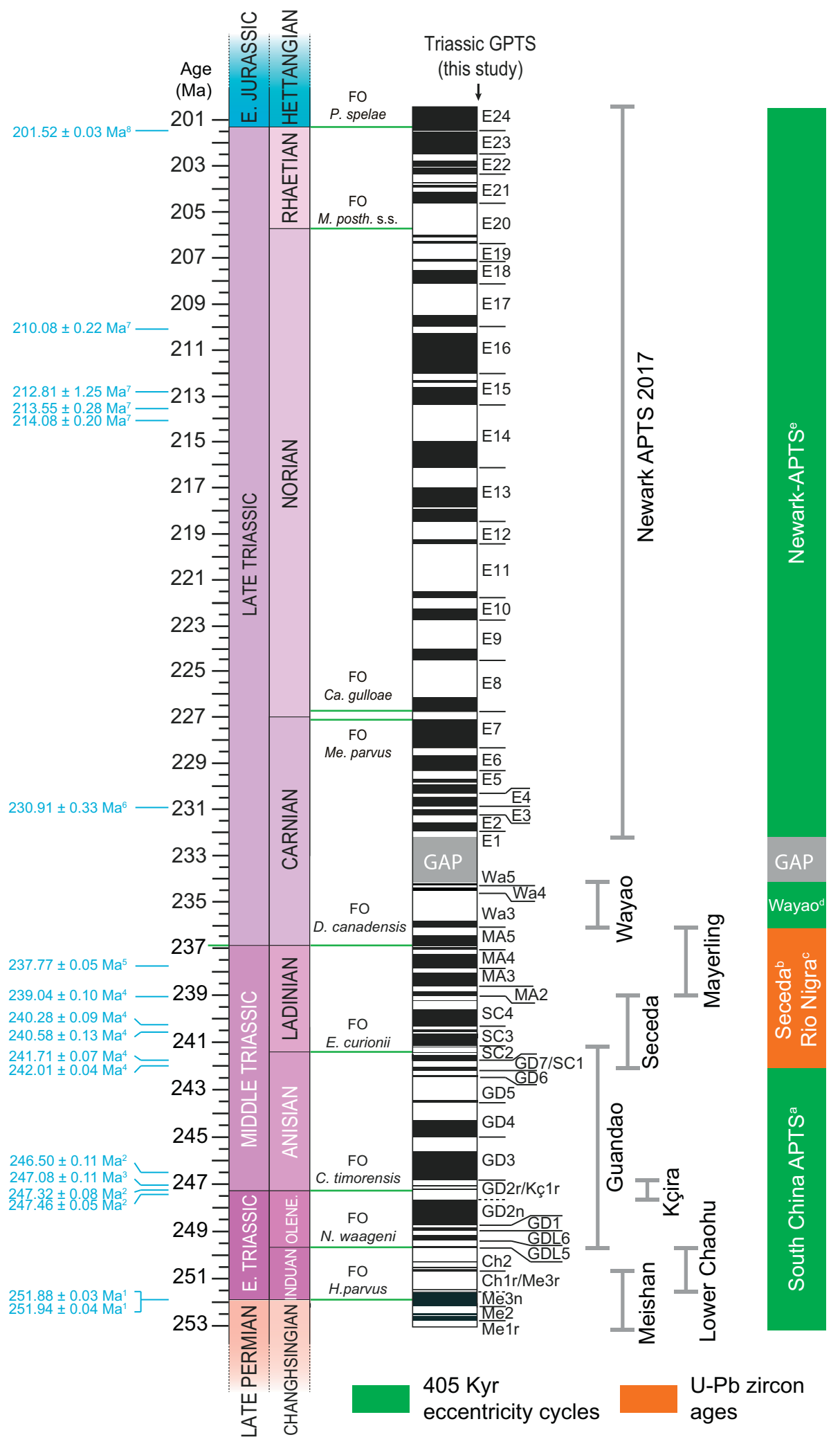

Fig. 14. Proposed geomagnetic polarity time scale (GPTS) for the Triassic, derived from a magnetostratigraphic composite of selected Tethyan marine sections integrated with key nonmarine sequences and $\mathrm{U}-\mathrm{Pb}$ dates and astrochonologies (Figures 11-13). Key U-Pb ages are on the left side of the GPTS (marked by blue lines), while on the right are reported the main biostratigraphic markers of the Stage boundaries (marked by green lines), the ranges of the reference stratigraphic sections used to compile the GPTS and the range of the age constraints used to compile the GPTS (astrochronology or U-Pb datings). References of the U-Pb ages are: 1 ) Burgess et al., 2014; 2) Lehrmann et al., 2015; 3) Lehrmann et al., 2006; 4) Wotzlaw et al., 2018; 5) Mietto et al., 2012; 6) Furin et al., 2006; 7) Kent et al., 2018; 8) Blackburn et al., 2013. References for the age constraints are: a) Li et al., 2016, 2018; b) Wotzlaw et al., 2018; c) Mietto et al., 2012; d) Zhang et al., 2015; e) Kent et al., 2017.
SC for Seceda, E for Newark, etc.; Fig. 14) Finally, we opted to exclude from our final composite GPTS (Fig. 14) polarity intervals based on single samples (represented as half bars in Figs. 11-13).

Potential errors propagating through the GPTS are those inherited from the radiometric and astrochronology methods applied, as well as the usual correlation uncertainties from provinciality of biozones and discontinuities in polarity records. For the Early Triassic and the early Late Triassic (Carnian), potential errors could be due to missing eccentricity ( 100 or $405 \mathrm{kyr}$ ) beats in the reference APTSs of South China (Li et al., 2016, 2018) and Wayao (Zhang et al., 2015) due, for example, to the presence of subtle gaps or unconformities, although no report in this sense has been presented by the above-referenced authors. Missing 


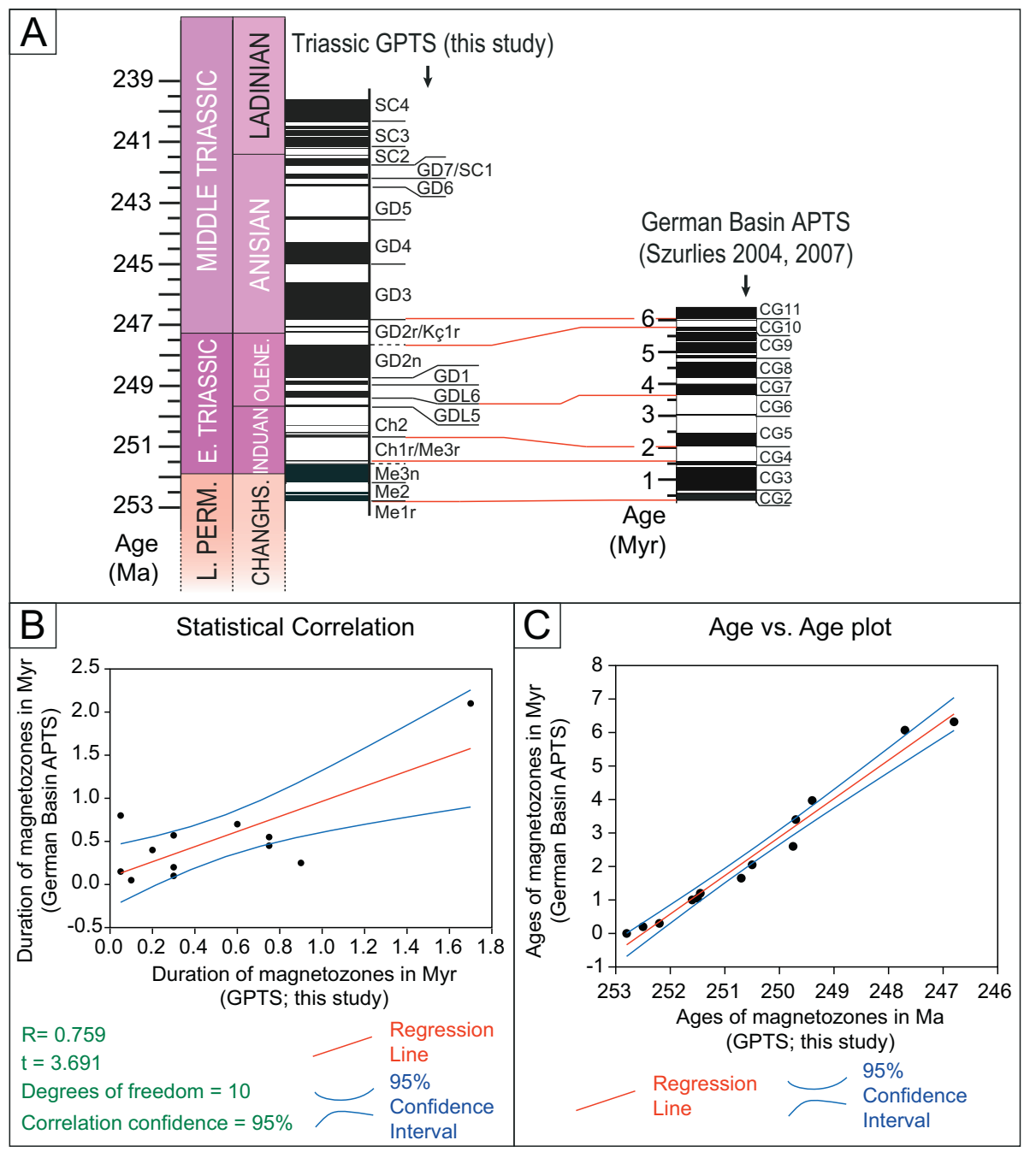

Fig. 15. A comparison between the Early Triassic APTS from the Germanic Basin (Szurlies, 2004, 2007) and the Early Triassic GPTS (this study) is shown in Panel A. Following the method outlined in Muttoni et al. (2004a), we obtained a best correlation option (red correlation lines) that optimizes the match between magnetozone durations in the GPTS of this study and the Germanic Basin APTS (Panel B with indication of correlation coefficient $R$ ). This optimal correlation is significant at $95 \%$ level according to a Student $\mathrm{t}$ test. The derived Age-Age function of this best correlation option is shown in Panel C. The 95\% confidence interval (blue line) associated to linear regression (red line) is marked in both the correlation (Panel B) and Age-Age plots (Panel C). See text for discussion. eccentricity ( $405 \mathrm{kyr}$ ) beats in the Late Triassic Newark-APTS (Kent et al., 2017) are much less probable, at least in the younger part of the APTS as recently confirmed by high-precision U-Pb zircon dates back to E14r from the Petrified Forest drill core (Kent et al., 2018). This leaves almost a $17 \mathrm{Myr}$ interval between available U-Pb dates of $214 \pm 0.2 \mathrm{Ma}$ from Petrified Forest correlated to E14r and $230.91 \pm 0.33$ Ma from Pignola 2 correlated to E4n that relies on the astrochronology of the Newark-APTS. In the case of the Middle Triassic, the reference Seceda age model is well controlled by a half-dozen U-Pb dates and mainly subject to errors defined through the $95 \%$ confidence limits of the Bayesian method used, which suggests maximum uncertainties of $\sim 200 \mathrm{kyr}$ (Wotzlaw et al., 2018).

When astrochronology is not available and the radiometric age tiepoints are wide apart, as in the late Ladinian-Early Carnian, we applied a simple linear interpolation between the nearest $\mathrm{U}-\mathrm{Pb}$ dates and accommodated sedimentation rates of the correlated sections accordingly. Errors in this interval are therefore inherited from the uppermost U-Pb age at Seceda (239.044 \pm 0.104; Wotzlaw et al., 2018) and the Rio Nigra U-Pb age (237.773 \pm 0.052; Mietto et al., 2012), while potential errors originating in the intervening interpolated part of the GPTS, based on magnetostratigraphic data from the apparently continuous Mayerling (Gallet et al., 1994, 1998) reference section, are at present not readily assessable. The various age constraints (and associated potential errors) adopted through the GPTS are shown in Fig. 14 (details on U-Pb age constraints in Middle Triassic, and associated errors, are provided in Supplemental Fig. S2).

\section{Comparison with other polarity timescales}

As described above, the Induan-Anisian (Early-early Middle Triassic) part of our composite GPTS is based on the same set of stratigraphic sections (Meishan, lower Chaohu, upper Chaohu, and Guandao) used in the South China APTS of Li et al. (2016, 2018), with however two notable differences concerning the use of the Guandao and Germanic Basin magnetostratigraphies. The Li et al. (2016, 2018) correlation grid had a gap in the Olenekian between the lower Chaohu and the upper Chaohu sections essentially because the lower part of the Guandao section from magnetozone GDL1 to GD1 (Lehrmann et al., 2006), which would nicely straddle the magnetostratigraphic gap, did not yield useful cyclostratigraphic data. Hence, the gap was filled by importing magnetostratigraphic and cyclostratigraphic data $(100 \mathrm{kyr}$ cycles) from cores in the continental Germanic Basin (Szurlies, 2004, 2007). Instead, giving priority to expanded records in stratigraphic continuity, we prefer to adopt the entire Guandao magnetostratigraphy (from magnetozone GDL1 at the base to magnetozone GD10 at the top), in association with Meishan and Chaohu, as the reference magnetostratigraphy for the Induan-Olenekian time interval (see Section 4.1). We then used the Germanic Basin magneto-cyclostratigraphy as an independent test to validate our GPTS following the correlation method outlined in Muttoni et al. (2004b). The Germanic Basin sequence in floating age coordinates (based on the $100 \mathrm{kyr}$ cycles; Szurlies, 2007) was placed aside the Early-early Middle Triassic portion of our GPTS. A linear correlation coefficient $(R)$ relating the duration of each of the $\mathrm{N}=12$ complete Germanic Basin polarity zones to the duration of the 
correlative chrons in our GPTS was calculated, from which a $t$ value was derived using the equation $t=R * \operatorname{sqrt}\left[(N-2) /\left(1-R^{2}\right)\right]$. The Germanic Basin sequence was then slid by two polarity zones along the GPTS, R and $t$ were recalculated, and the exercise was repeated until all possibilities in the Early-early Middle Triassic interval were explored. We obtained a positive statistical correlation match (significant at $95 \%$ level) that is stratigraphically meaningful and provides support for the validity of both timescales and the duration of the Early Triassic (Fig. 15; preferred correlation option is shown in Panel A; the statistical parameters $\mathrm{R}$ and $\mathrm{t}$ are shown with the preferred linear correlation option plot in Panel B). An age-age plot has been obtained according to the preferred correlation between the Early Triassic GPTS and the Germanic Basin APTS (Fig. 15C), showing slight deviations from linearity that could be imputable to the uncertainty of cycle-derived ages between the Early Triassic GPTS and the Germanic Basin APTS.

As stated previously, our revised Triassic GPTS shows differences relative to Hounslow and Muttoni (2010) that essentially arise from the use we make here of magnetozone sequences and nomenclatures from a more strict inventory of Tethyan marine sections for the Early-Middle Triassic, less strict reliance on biozones for correlation, as well as the availability since 2010 of additional magneto-bio-cyclostratigraphic data (e.g., Maron et al., 2015; Li et al., 2016; this study) sometimes calibrated with new U-Pb zircon dates and age models (e.g., Wotzlaw et al., 2018; this study). Moreover, we adopted here the entire Newark APTS as key reference timescale for the Late Triassic (Late Carnian-Rhaetian), onto which fossil-based stage boundaries and U-Pb ages have been traced from various Tethyan marine sections by means of magnetostratigraphy, whereas Hounslow and Muttoni (2010) opted for a composite Late Triassic sequence based exclusively on Tethyan marine sections, which was tested against the Newark APTS according to three correlation options (A, B, C; figure 12 in Hounslow and Muttoni, 2010).

These differences are inevitably reflected also in the Ogg (2012b) timescale that uses for the Triassic a slightly modified version of the Hounslow and Muttoni (2010) timescale [for example, see the debate in Ogg (2012b) on the "long-Tuvalian" versus "long-Rhaetian" correlation options that derives from options A vs. B in Hounslow and Muttoni (2010)]. Differences of our Triassic GPTS are relatively reduced relative to the more recent Ogg et al. (2016) timescale that adopts, as we do, the South China APTS of Li et al. (2016) for the Early Triassic (but see above), and a Late Triassic composite magnetostratigraphy that is still derived from Hounslow and Muttoni (2010) but is correlated to the Newark APTS according to the "long-Rhaetian" option (essentially equivalent to option A of Hounslow and Muttoni, 2010) that is more consistent with our solution (see also Muttoni et al., 2010; Maron et al., 2015). Finally, our GPTS differs from Hounslow et al. (2018) insofar as these authors averaged the durations (or thicknesses) of magnetozones from correlative sections, thus obtaining a composite average magnetozone sequence, whereas we chose to select key sections for each chronostratigraphic interval and use them as reference sections for the GPTS construction.

\section{Conclusions}

We presented the magnetostratigraphy of the Rio Nigra and Rio Frommer sections from the Dolomites calibrated with a U-Pb zircon date of $237.77 \pm 0.05 \mathrm{Ma}$ and provided with ammonoid and conodont biostratigraphy. These new data contribute to the chronology of the Ladinian, represented thus far mainly by the radiometrically unconstrained Mayerling marine section (Gallet et al., 1994, 1998). Using these new data in conjunction with a total of 35 selected magnetostratigraphic sequences from the literature, we constructed an updated Triassic GPTS from the Permian/Triassic boundary to the Triassic/ Jurassic boundary (Newark APTS for the Late Carnian-Rhaetian) for a total duration of $\sim 50.5 \mathrm{Myr}$.

Stage boundaries correlated to the GPTS are as follows: Permian/
Triassic boundary at $251.9 \mathrm{Ma}$ based on $\mathrm{U}-\mathrm{Pb}$ zircon dates around the FO of conodont Hindeodus parvus at the Meishan GSSP, China. Induan/ Olenekian boundary at $249.7 \mathrm{Ma}$, astrochronological age of the FO of conodont Neospathodus waageni at Guandao (China). Olenekian/Anisian boundary at $247.3 \mathrm{Ma}$ based on U-Pb dates around the FO of conodont Chiosella timorensis at Guandao, China. Anisian/Ladinian boundary at 241.5 Ma based on U-Pb zircon dates from Seceda, Italy, of a level correlated to the base of the Eoprotrachyceras curionii ammonoid Zone at the Bagolino GSSP, Italy. Ladinian/Carnian boundary at $236.8 \mathrm{Ma}$, estimated age of the FO of ammonoid Daxatina canadensis at the Prati di Stuores GSSP. Carnian/Norian boundary at $\sim 227 \mathrm{Ma}$, estimated age of a level between the FOs of conodonts Metapolygnathus parvus and Carnepigondolella gulloae at Pizzo Mondello, Italy. Norian/Rhaetian boundary at $205.7 \mathrm{Ma}$, estimated age of FO of conodont Misikella posthernsteini sensu stricto at Pignola-Abriola, Italy. Triassic/Jurassic boundary at 201.4 Ma, based on U-Pb zircon age of the FO of ammonite Psiloceras spelae at Levanto section, Peru.

According to these stage boundary ages, the Induan Stage (251.9-249.7 Ma) is estimated to be $\sim 2.2 \mathrm{Myr}$-long, the Olenekian Stage (249.7-247.3 Ma) $\sim 2.4$ Myr-long, the Anisian Stage (247.3-241.5 Ma) 5.8 Myr-long, the Ladinian Stage (241.5-236.8 Ma) $\sim 4.7$ Myr-long, the Carnian Stage (236.8-227 Ma) 9.8 Myr-long, the Norian Stage (227-205.7 Ma) 21.3 Myr-long, and the Rhaetian Stage (205.7-201.4 Ma) 4.3 Myr-long. The average geomagnetic polarity reversal frequency for the Early Triassic (251.9-247.3 Ma) is $\sim 3 \mathrm{rev} /$ Myr, of the Middle Triassic (247.3-236.8 Ma) is $\sim 2.5 \mathrm{rev} / \mathrm{Myr}$, and of the Late Triassic (236.8-201.4 Ma) is $\sim 1.4 \mathrm{rev} / \mathrm{Myr}$ (Supplementary Table S2).

Main future improvements of this timescale would include filling the Carnian magnetobiostratigraphic gap between Wayao, Pignola-2, and the base of the Newark APTS; improving coverage in the Ladinian interval presently represented by the upper Seceda and lower Mayerling sections; and providing additional numeric age constraints for the Ladinian/Carnian, Carnian/Norian, and Norian/Rhaetian boundaries. Another improvement would be to delineate new magnetostratigraphic sections containing the $405 \mathrm{kyr}$ climate beat, which is likely to have a fixed single period back to the base of the Triassic.

Supplementary online material (available in Mendeley Data Repository) includes the following data: ChRM data (Supplemental Table S1); ages and durations of the GPTS chrons and reversal frequencies in the Early, Middle and Late Triassic (Supplemental Table S2). Stereograms of Anisotropy of Magnetic Susceptibility (AMS), F-L plots and Jelinek plots are available as Supplemental Fig. S1. A plot with the U-Pb age constraints used to build the Middle Triassic GPTS, and related errors, is available as Supplemental Fig. S2. Supplementary data associated with this article can be found in the online version, at doi: https://doi.org/10.1016/j.palaeo.2018.11.024.

\section{Acknowledgments}

This research was supported by IAS (International Association of Sedimentologists) Post-doctoral Research Grant 2016 to Matteo Maron. Funding for this research was provided through PRAT CPDA152211/15 to Manuel Rigo by the University of Padova. Dennis Kent thanks the US National Science Foundation (Sedimentary Geology and Paleobiology Program) and the Director of Lamont-Doherty Earth Observatory for support of his contribution to this research. LDEO Contribution \#8268. The authors wish to thank anonymous Reviewer 1 and Reviewer 2 (Mark Hounslow) for their valuable comments. The authors would like to dedicate this paper to the late Maurizio Gaetani (1940 - 2017).

\section{References}

Bernardi, M., Gianolla, P., Petti, F.M., Mietto, P., Benton, M.J., 2018. Dinosaur diversification linked with the Carnian Pluvial Episode. Nat. Commun. 9 (1499). https:// doi.org/10.1038/s41467-018-03996-1. 
Bertinelli, A., Casacci, M., Concheri, G., Gattolin, G., Godfrey, L., Katz, M.E., Maron, M., Mazza, M., Mietto, P., Muttoni, G., Rigo, M., Sprovieri, M., Stellin, F., Zaffani, M., 2016. The Norian/Rhaetian boundary interval at Pignola-Abriola section (southern Apennines, Italy) as a GSSP candidate for the Rhaetian Stage: an update. Albertiana 43, 5-18.

Bhargava, O.N., Krystyn, L., Balini, M., Lein, R., Nicora, A., 2004. Revised litho- and sequence stratigraphy of the Spiti Triassic. Albertiana 30, 21-39.

Blackburn, T.J., Olsen, P.E., Browning, S.A., McLean, N.M., Kent, D.V., Puffer, J., McHone, G., Rasbury, E.T., Et-Touhami, M., 2013. Zircon U-Pb geochronology links the End-Triassic extinction with the Central Atlantic Magmatic Province. Science 340, 941-945. https://doi.org/10.1126/science.1234204.

Brack, P., Muttoni, G., 2000. High-resolution magnetostratigraphic and lithostratigraphic correlations in Middle Triassic pelagic carbonates from the Dolomites (northern Italy). Palaeogeogr. Palaeoclimatol. Palaeoecol. 161 (3-4), 361-380. https://doi.org/ 10.1016/S0031-0182(00)00081-X.

Brack, P., Rieber, H., Nicora, A., Mundil, R., 2005. The Global Boundary Stratotype Section and Point (GSSP) of the Ladinian Stage (Middle Triassic) at Bagolino (Southern Alps, Northern Italy) and its implications for the Triassic time scale. Episodes 28 (4), 233-244. https://doi.org/10.1130/0091-7613(1996) $024<0371$ :BARADQ $>2.3 . \mathrm{CO} ; 2$.

Broglio Loriga, C., Cirilli, S., De Zanche, V., Di Bari, D., Gianolla, P., Laghi, G.F., Lowrie, W., Manfrin, S., Mastandrea, A., Mietto, P., Muttoni, G., Neri, C., Posenato, R., Rechichi, M., Rettori, R., Roghi, G., 1999. The Prati di Stuores/Stuores Wiesen section (Dolomites, Italy): a candidate Global Stratotype Section and Point for the base of the Carnian Stage. Riv. Ital. Paleontol. Stratigr. 105 (1), 37-78. https://doi.org/10. 13130/2039-4942/5365.

Burgess, S.D., Bowring, S., Shen, S.-z., 2014. High-precision timeline for Earth's most severe extinction. Proc. Natl. Acad. Sci. U.S.A. 111 (13), 3316-3321. https://doi.org/ 10.1073/pnas.1317692111.

Channell, J.E.T., Kozur, H.W., Sievers, T., Mock, R., Aubrecht, R., Sykora, M., 2003. Carnian-Norian biomagnetostratigraphy at Silická Brezová (Slovakia): correlation to other Tethyan sections and to the Newark Basin. Palaeogeogr. Palaeoclimatol. Palaeoecol. 191 (2), 65-109. https://doi.org/10.1016/S0031-0182(02)006545.

Dal Corso, J., Marzoli, A., Tateo, F., Jenkyns, H.C., Bertrand, H., Youbi, N., Mahmoudi, A., Font, E., Buratti, N., Cirilli, S., 2014. The dawn of CAMP volcanism and its bearing on the end-Triassic carbon cycle disruption. J. Geol. Soc. 171, 153-164. https://doi.org/ 10.1144/jgs2013-063.

Davies, J.H.F.L., Marzoli, A., Bertrand, H., Youbi, N., Ernesto, M., Schaltegger, U., 2017. End-Triassic mass extinction started by intrusive CAMP activity. Nat. Commun. 8, 15596. https://doi.org/10.1038/ncomms15596.

De Zanche, V., Gianolla, P., Mietto, P., Siorpaes, C., Vail, P.R., 1993. Triassic Sequence Stratigraphy in the Dolomites (Italy). Mem. Sci. Geol. 45, 1-27.

Deenen, M.H.L., Ruhl, M., Bonis, N.R., Krijgsman, W., Kuerschner, W.M., Reitsma, M., van Bergen, M.J., 2010. A new chronology for the end-Triassic mass extinction. Earth Planet. Sci. Lett. 291 (1-4), 113-125. https://doi.org/10.1016/j.epsl.2010.01.003.

Fisher, R., 1953. Dispersion on a sphere. Proc. R. Soc. Lond. 217 (1130), 295-305. https://doi.org/10.1098/rspa.1953.0064.

Furin, S., Preto, N., Rigo, M., Roghi, G., Gianolla, P., Crowley, J.L., Bowring, S.A., 2006. High-precision U-Pb zircon age from the Triassic of Italy: implications for the Triassic time scale and the Carnian origin of calcareous nanoplankton and dinosaurs. Geology 34 (12), 1009-1012. https://doi.org/10.1130/G22967A.1.

Galfetti, T., Bucher, H., Ovtcharova, M., Schaltegger, U., Brayard, A., Brühwiler, T., Goudemand, N., Weissert, H., Hochuli, P.A., Cordey, F., Guodun, K., 2007. Timing of the Early Triassic carbon cycle perturbation inferred from new U-Pb ages and ammonoid biochronozones. Earth Planet. Sci. Lett. 258 (3-4), 593-604. https://doi.org/ 10.1016/j.epsl.2007.04.023.

Gallet, Y., Besse, J., Krystyn, L., Marcoux, J., Théveniaut, H., 1992. Magnetostratigraphy of the Late Triassic Bolucektasi Tepe section (southwestern Turkey): implications for changes in magnetic reversal sequency. Phys. Earth Planet. Inter. 73 (1-2), 85-108. https://doi.org/10.1016/0031-9201(92)90109-9.

Gallet, Y., Besse, J., Krystyn, L., Théveniaut, H., Marcoux, J., 1994. Magnetostratigraphy of the Mayerling section (Austria) and Erenkolu Mezarlik (Turkey) section: Improvement of the Carnian (late Triassic) magnetic polarity time scale. Earth Planet. Sci. Lett. 125 (1-4), 173-191. https://doi.org/10.1016/0012-821X(94)90214-3.

Gallet, Y., Krystyn, L., Besse, J., 1998. Upper Anisian to Lower Carnian magnetostratigraphy from the Northern Calcareous Alps (Austria). J. Geophys. Res. 103 (B1), 605-621. https://doi.org/10.1029/97JB02155.

Gallet, Y., Krystyn, L., Besse, J., Saidi, A., Ricou, L.-E., 2000a. New constraints of the Upper Permian and Lower Triassic geomagnetic polarity timescale from the Abadeh section (central Iran). J. Geophys. Res. 105 (B2), 2805-2815. https://doi.org/10. 1029/1999JB900218.

Gallet, Y., Besse, J., Krystyn, L., Marcoux, J., Guex, J., Théveniaut, H., 2000 b. Magnetostratigraphy of the Kaavalani section (southwestern Turkey): consequences for the origin of the Antalya Calcareous Nappes (Turkey) and for Norian (Late Triassic) magnetic polarity timescale. Geophys. Res. Lett. 27 (14), 2033-2036. https://doi.org/10.1029/2000GL008504.

Gallet, Y., Krystyn, L., Besse, J., Marcoux, J., 2003. Improving the Upper Triassic numerical time scale from cross-correlation between Tethyan marine sections and the continental Newark basin sequence. Earth Planet. Sci. Lett. 212 (3-4), 255-261. https://doi.org/10.1016/S0012-821X(03)00290-5.

Gialanella, P.R., Heller, F., Mietto, P., Incoronato, A., De Zanche, V., Gianolla, P., Roghi, G., 2001. Magnetostratigraphy and biostratigraphy of the Middle Triassic Margon section (Southern Alps, Italy). Earth Planet. Sci. Lett. 187 (1-2), 17-25. https://doi. org/10.1016/S0012-821X(01)00275-8.

Gianolla, P., De Zanche, V., Mietto, P., 1998. Triassic sequence stratigraphy in the southern Alps (northern Italy): definition of sequences and basin evolution. In:
Gracianscky, P., Hardenbol, J., Jacquin, T., Vail, P. (Eds.), Mesozoic and Cenozoic Sequence Stratigraphy of European Basins. Sedimentary Petrology Magazine Special Publications. vol. 60. pp. 719-747.

Giordano, N., Rigo, M., Ciarapica, G., Bertinelli, A., 2010. New biostratigraphical constraints for the Norian/Rhaetian boundary: data from Lagonegro Basin, Southern Apennines, Italy. Lethaia 43 (4), 573-586. https://doi.org/10.1111/j.1502-3931. 2010.00219.x.

Glen, J.M., Nomade, S., Lyons, J.L., Metcalfe, I., Mundil, R., Renne, P.R., 2009. Magnetostratigraphic correlations of Permian-Triassic marine-terrestrial sections from China. J. Asian Earth Sci. 36 (6), 521-540. https://doi.org/10.1016/j.jseaes. 2009.03.003.

Gradinaru, E., Orchard, M.J., Nicora, A., Gallet, Y., Besse, J., Krystyn, L., Sobolev, E.S., Atudorei, N.V., Ivanova, D., 2007. The Global Boundary Stratotype Section and Point (GSSP) for the base of the Anisian Stage: Deşli Caira Hill, North Dobrogea, Romania. Albertiana 36, 54-67.

Guex, J., Bartolini, A., Atudorei, V., Taylor, D., 2004. High resolution ammonite and carbon isotope stratigraphy across the Triassic-Jurassic boundary at New York Canyon (Nevada). Earth Planet. Sci. Lett. 225 (1-2), 29-41. https://doi.org/10.1016/ j.epsl.2004.06.006.

Guex, J., Schoene, B., Bartolini, A., Spangenberg, J., Schaltegger, U., O'Dogherty, L., Taylor, D., Bucher, H., Atudorei, V., 2012. Geochronological constraints on post-extinction recovery of the ammonoids and carbon cycle perturbations during the Early Jurassic. Palaeogeogr. Palaeoclimatol. Palaeoecol. 346-347, 1-11. https://doi.org/ 10.1016/j.palaeo.2012.04.030.

Hesselbo, S.P., Robinson, S.A., Surlyk, F., Piasecki, S., 2002. Terrestrial and marine extinction at the Triassic-Jurassic boundary synchronized with major carbon-cycle perturbation: a link to initiation of massive volcanism? Geology 30 (3), 251-254. https://doi.org/10.1130/0091-7613(2002)030<0251:TAMEAT > 2.0.CO;2.

Hesselbo, S.P., Robinson, S.A., Surlyk, F., 2004. Sea-level change and facies development across potential Triassic-Jurassic boundary horizons, SW Britain. J. Geol. Soc. 161 (3), 365-379. https://doi.org/10.1144/0016-764903-033.

Hesselbo, S.P., McRoberts, C.A., Palfy, J., 2007. Triassic-Jurassic boundary events: problems, progress, possibilities. Palaeogeogr. Palaeoclimatol. Palaeoecol. 244 (1-4), 1-10. https://doi.org/10.1016/j.palaeo.2006.06.020.

Hillebrandt, A.V., Krystyn, L., Kürschner, W.M., Bonis, N.R., Ruhl, M., Richoz, S., Schobben, M.A.N., Urlichs, M., Bown, P.R., Kment, K., McRoberts, C.A., Simms, M., Tomasovych, A., 2013. The Global Stratotype Sections and Point (GSSP) for the base of the Jurassic system at Kuhjoch (Karwendel Mountains, Northern Calcareous Alps, Tyrol, Austria). Episodes 36, 162-198.

Hochuli, P.A., Roghi, G., Brack, P., 2015. Palynological zonation and particulate organic matter of the Middle Triassic of the Southern Alps (Seceda and Val Gola-Margon sections, Northern Italy). Rev. Palaeobot. Palynol. 218, 28-47. https://doi.org/10 1016/j.revpalbo.2014.07.006.

Holmes, M.A., 1995. Pedogenic alteration of basalts recovered during Leg 144. In: Haggerty, J.A., Premoli Silva, I., Rack, F., McNutt, M.K. (Eds.), Proceedings of the Ocean Drilling Program, Scientific Results. vol. 144. pp. 381-398.

Hounslow, M.W., Muttoni, G., 2010. The geomagnetic polarity timescale for the Triassic: linkage to stage boundary definitions. In: Lucas, S.G. (Ed.), The Triassic Timescale. vol. 334. Geological Society of London, Special Publications, pp. 61-102. https://doi. org/10.1144/SP334.4.

Hounslow, M.W., Posen, P.E., Warrington, G., 2004. Magnetostratigraphy and biostratigraphy of the Upper Triassic and lowermost Jurassic succession, St. Audrie's Bay, UK. Palaeogeogr. Palaeoclimatol. Palaeoecol. 213 (3-4), 331-358. https://doi.org/10. 1016/j.palaeo.2004.07.018.

Hounslow, M.W., Domeier, M., Biggin, A.J., 2018. Subduction flux modulates the geomagnetic polarity reversal rate. Tectonophysics 742-743, 34-49. https://doi.org/10. 1016/j.tecto.2018.05.018.

Jelinek, V., 1981. Characterization of the magnetic fabrics of rocks. Tectonophysics 79 (3-4), T63-T67. https://doi.org/10.1016/0040-1951(81)90110-4.

Kent, D.V., Olsen, P.E., 1999. Astronomically tuned geomagnetic polarity time scale for the Late Triassic. J. Geophys. Res. 104 (B6), 12831-12841. https://doi.org/10.1029/ 1999JB900076.

Kent, D.V., Olsen, P.E., Witte, W.K., 1995. Late Triassic-earliest Jurassic geomagnetic polarity sequence and paleolatitudes from drill cores in the Newark rift basin, eastern North America. J. Geophys. Res. 100 (B8), 14965-14998. https://doi.org/10.1029/ 95JB01054.

Kent, D.V., Muttoni, G., Brack, P., 2004. Magnetostratigraphic confirmation of a much faster tempo for sea-level change for the Middle Triassic Latemar platform carbonates. Earth Planet. Sci. Lett. 228 (3-4), 369-377. https://doi.org/10.1016/j.epsl. 2004.10.017.

Kent, D.V., Olsen, P.E., Muttoni, G., 2017. Astrochronostratigraphic polarity time scale (APTS) for the Late Triassic and Early Jurassic from continental sediments and correlation with standard marine stages. Earth Sci. Rev. 166, 153-180. https://doi.org/ 10.1016/j.earscirev.2016.12.014.

Kent, D.V., Olsen, P.E., Rasmussen, C., Lepre, C., Mundil, R., Irmis, R.B., Gehrels, G.E., Giesler, D., Geissman, J.W., Parker, W.G., 2018. Empirical evidence for stability of the 405-kiloyear Jupiter-Venus eccentricity cycle over hundreds of million years. Proc. Natl. Acad. Sci. U.S.A. 6153-6158. https://doi.org/10.1073/pnas.1800891115.

Krystyn, L., 1983. Das Epidaurus-Profil (Griechenland) - ein Beitrag zur ConodontenStandardzonierung des tethyalen Ladin un Unterkarn. In: Zapfe, H. (Ed.), Neue Beiträge zur Biostratigraphie der Tethys-Trias. Schriftenreihe der Erdwissenschaftlichen Kommissionen, Österreichisches Akademie der Wissenschaften, vol. 5. pp. 231-258.

Krystyn, L., Gallet, Y., Besse, J., Marcoux, J., 2002. Integrated Upper Carnian to Lower Norian biochronology and implications for the Upper Triassic magnetic polarity time scale. Earth Planet. Sci. Lett. 203 (1), 343-351. https://doi.org/10.1016/S0012-821X 
(02)00858-0.

Krystyn, L., Balini, M., Nicora, A., 2004. Lower and Middle Triassic stage and substage boundaries in Spiti. Albertiana 30, 40-53.

Krystyn, L., Bouquerel, H., Kürschner, W., Richoz, S., Gallet, Y., 2007a. Proposal for a candidate GSSP for the base of the Rhaetian Stage. In: Lucas, S.G., Spielmann, J.A. (Eds.), The Global Triassic. 41. New Mexico Museum of Natural History and Science Bulletin, pp. 189-199.

Krystyn, L., Richoz, S., Gallet, Y., Bouquerel, H., Kürschner, W.M., Spötl, C., 2007b. Updated bio- and magnetostratigraphy from Steinbergkogel (Austria), candidate and GSSP for the base of the Rhaetian stage. Albertiana 36, 164-173.

Lehrmann, D.J., Ramezani, J., Bowring, S.A., Martin, M.W., Montgomery, P., Enos, P., Payne, J.L., Orchard, M.J., Hongmei, W., Jiayong, W., 2006. Timing of recovery from end-Permian extinction: geochronologic and biostratigraphic constraints from south China. Geology 34 (12), 1053-1056. https://doi.org/10.1130/G22827A.1.

Lehrmann, D.J., Stepchinski, L., Altiner, D., Orchard, M.J., Montgomery, P., Enos, P., Elwood, B.B., Bowring, S.A., Ramezani, J., Wang, H., Wei, J., Yu, M., Griffiths, J.D., Minzoni, M., Schaal, E.K., Li, X., Meyer, K.M., Payne, J.L., 2015. An integrated biostratigraphy (conodonts and foraminifers) and chronostratigraphy (paleomagnetic reversals, magnetic susceptibility, elemental chemistry, carbon isotopes and geochronology) for the Permian-Upper Triassic strata of Guandao section, Nanpanjiang Basin, South China. J. Asian Earth Sci. 108, 117-135. https://doi.org/10.1016/j. jseaes.2015.04.030.

Li, H., Wang, J., 1989. Magnetostratigraphy of the Permo-Triassic boundary section of Meishan of Cangxing, Zhejang. Sci. China 8, 652-658.

Li, M., Ogg, J., Zhang, Y., Huang, C., Hinnov, L., Chen, Z.-Q., Zou, Z., 2016. Astronomical tuning of the end-Permian extinction and the Early Triassic Epoch of South China and Germany. Earth Planet. Sci. Lett. 441, 10-25. https://doi.org/10.1016/j.epsl.2016. 02.017

Li, M., Huang, C., Hinnov, L., Chen, W., Ogg, J., Tian, W., 2018. Astrochronology of the Anisian stage (Middle Triassic) at the Guandao reference section, South China. Earth Planet. Sci. Lett. 482, 591-606. https://doi.org/10.1016/j.epsl.2017.11.042.

Lowrie, W., 1990. Identification of ferromagnetic minerals in a rock by coercivity and unblocking temperature properties. Geophys. Res. Lett. 17, 159-162. https://doi.org/ 10.1029/GL017i002p00159.

Lucas, S.G., Tanner, L.H., 2018. The missing mass extinction at the Triassic-Jurassic boundary. In: Tanner, L.H. (Ed.), The Late Triassic World: Earth in a Time of Transition. Topics in Geobiology. vol. 46. pp. 721-785. https://doi.org/10.1007/ 978-3-319-68009-5 15.

Maron, M., Rigo, M., Bertinelli, A., Katz, M.E., Godfrey, L., Zaffani, M., Muttoni, G., 2015. Magnetostratigraphy, biostratigraphy, and chemostratigraphy of the Pignola-Abriola section: new constraints for the Norian-Rhaetian boundary. Geol. Soc. Am. Bull. 127 (7-8), 962-974. https://doi.org/10.1130/B31106.1.

Maron, M., Muttoni, G., Dekkers, M.J., Mazza, M., Roghi, G., Breda, A., Krijgsman, W., Rigo, M., 2017. Contribution to the magnetostratigraphy of the Carnian: new magneto-biostratigraphic constraints from Pignola-2 and Dibona marine sections, Italy. Newsl. Stratigr. 50 (2), 187-203. https://doi.org/10.1127/nos/2017/0291.

Marzoli, A., Bertrand, H., Knight, K.B., Cirilli, S., Buratti, N., Vérati, C., Nomade, S., Renne, P.R., Youbi, N., Martini, R., Allenbach, K., Neuwerth, R., Rapaille, C., Zaninetti, L., Bellieni, G., 2004. Synchrony of the Central Atlantic magmatic province and the Triassic-Jurassic boundary climatic and biotic crisis. Geology 32 (11), 973-976. https://doi.org/10.1130/G20652.1.

Mazza, M., Furin, S., Spötl, C., Rigo, M., 2010. Generic turnovers of Carnian/Norian conodonts: climatic control or competition? Palaeogeogr. Palaeoclimatol. Palaeoecol. 290 (1-4), 120-137. https://doi.org/10.1016/j.palaeo.2009.07.006.

Mazza, M., Rigo, M., Nicora, A., 2011. A new Metapolygnathus platform conodont species and its implications for Upper Carnian global correlations. Acta Palaeontol. Pol. 56 (1), 121-131. https://doi.org/10.4202/app.2009.1104.

Mazza, M., Rigo, M., Gullo, M., 2012a. Taxonomy and biostratigraphic record of the Upper Triassic conodonts of the Pizzo Mondello section (western Sicily, Italy), GSSP candidate for the base of the Norian. Riv. Ital. Paleontol. Stratigr. 118 (1), 85-130. https://doi.org/10.13130/2039-4942/5993.

Mazza, M., Cau, A., Rigo, M., 2012b. Application of numerical cladistic analyses to the Carnian-Norian conodonts: a new approach for phylogenetic interpretations. J. Syst. Palaeontol. 10 (3), 401-422. https://doi.org/10.1080/14772019.2011.573584.

Meyers, S.R., 2008. Resolving Milankovitchian controversies: the Triassic Latemar Limestone and the Eocene Green River Formation. Geology 36 (4), 319-322. https:// doi.org/10.1130/G24423A.1.

Mietto, P., Manfrin, S., 1995. A high resolution Middle Triassic ammonoid standard scale in the Tethys Realm. A preliminary report. Bull. Soc. Geol. Fr. 166 (5), 539-563. https://doi.org/10.2113/gssgfbull.166.5.539.

Mietto, P., Manfrin, S., Preto, N., Gianolla, P., 2008. Selected ammonoid fauna from Prati di Stuores/Stuores Wiesen and related sections across the Ladinian-Carnian boundary (Southern Alps, Italy). Riv. Ital. Paleontol. Stratigr. 114 (3), 377-429. https://doi. org/10.13130/2039-4942/5909.

Mietto, P., Manfrin, S., Preto, N., Rigo, M., Roghi, G., Furin, S., Gianolla, P., Posenato, R., Muttoni, G., Nicora, A., Buratti, N., Cirilli, S., Spötl, C., Ramezani, J., Bowring, S.A., 2012. The Global Stratotype Section and Point (GSSP) of the Carnian Stage (Late Triassic) at Prati di Stuores/Stuores Wiesen Section (Southern Alps, NE Italy). Episodes 35 (3), 414-430.

Mundil, R., Zühlke, R., Bechstädt, T., Peterhänsel, A., Egenhoff, S.O., Oberli, F., Meier, M., Brack, P., Rieber, H., 2003. Cyclicities in Triassic platform carbonates: synchronizing radio-isotopic and orbital clocks. Terra Nova 15 (2), 81-87. https://doi.org/10.1046/ j.1365-3121.2003.00475.x.

Mundil, R., Ludwig, K.R., Metcalfe, I., Renne, P.R., 2004. Age and timing of the Permian Mass Extinction: U/Pb dating of closed-system zircons. Science 305 (5691),

1760-1763. https://doi.org/10.1126/science.1101012.
Muttoni, G., Kent, D.V., Gaetani, M., 1995. Magnetostratigraphy of the Lower-Middle Triassic boundary section from Chios (Greece). Phys. Earth Planet. Inter. 92 (3-4), 245-260. https://doi.org/10.1016/0031-9201(95)03021-4.

Muttoni, G., Kent, D.V., Meço, S., Nicora, A., Gaetani, M., Balini, M., Germani, D., Rettori, R., 1996a. Magnetostratigraphy of the Spathian to Anisian (Lower to Middle Triassic) Kçira section, Albania. Geophys. J. Int. 127 (2), 503-514. https://doi.org/10.1111/j. 1365-246X.1996.tb04736.x.

Muttoni, G., Kent, D.V., Nicora, A., Rieber, H., Brack, P., 1996b. Magneto-biostratigraphy of the 'Buchenstein Beds' at Frötschbach (Western Dolomites, Italy). Albertiana 17, 51-56.

Muttoni, G., Kent, D.V., Brack, P., Nicora, A., Balini, M., 1997. Middle Triassic magnetobiostratigraphy from the Dolomites and Greece. Earth Planet. Sci. Lett. 146, 107-120.

Muttoni, G., Kent, D.V., Meço, S., Balini, M., Nicora, A., Rettori, R., Gaetani, M., Krystyn, L., 1998. Towards a better definition of the Middle Triassic magnetostratigraphy and biostratigraphy in the Tethyan realm. Earth Planet. Sci. Lett. 164 (1-2), 285-302. https://doi.org/10.1016/S0012-821X(98)00215-5.

Muttoni, G., Nicora, A., Brack, P., Kent, D.V., 2004a. Integrated Anisian-Ladinian boundary chronology. Palaeogeogr. Palaeoclimatol. Palaeoecol. 208 (1-2), 85-102. https://doi.org/10.1016/j.palaeo.2004.02.030.

Muttoni, G., Kent, D.V., Olsen, P.E., Di Stefano, P., Lowrie, W., Bernasconi, S., Hernandez F.M., 2004b. Tethyan magnetostratigraphy from Pizzo Mondello (Sicily) and correlation to the Late Triassic Newark astrochronological polarity time scale. Geol. Soc. Am. Bull. 116 (9-10), 1043-1058. https://doi.org/10.1130/B25326.1.

Muttoni, G., Kent, D.V., Jadoul, F., Olsen, P.E., Rigo, M., Galli, M.T., Nicora, A., 2010 Rhaetian magneto-biostratigraphy from the Southern Alps (Italy): Constraints on Triassic chronology. Palaeogeogr. Palaeoclimatol. Palaeoecol. 285 (1-2), 1-16. https://doi.org/10.1016/j.palaeo.2009.10.014.

Muttoni, G., Dallanave, E., Channell, J.E.T., 2013. The drift history of Adria and Africa from 280 Ma to Present, Jurassic true polar wander, and zonal climate control on Tethyan sedimentary facies. Palaeogeogr. Palaeoclimatol. Palaeoecol. 386, 415-435. https://doi.org/10.1016/j.palaeo.2013.06.011.

Muttoni, G., Mazza, M., Mosher, D., Katz, M.E., Kent, D.V., Balini, M., 2014. A MiddleLate Triassic (Ladinian-Rhaetian) carbon and oxygen isotope record from the Tethyan Ocean. Palaeogeogr. Palaeoclimatol. Palaeoecol. 399, 246-259. https://doi.org/10. 1016/j.palaeo.2014.01.018.

Muttoni, G., Tartarotti, P., Chiari, M., Marieni, C., Rodelli, D., Dallanave, E., Kirscher, U., 2015. Paleolatitudes of Late Triassic radiolarian cherts from Argolis, Greece: insights on the paleogeography of the western Tethys. Palaeogeogr. Palaeoclimatol. Palaeoecol. 417, 476-490. https://doi.org/10.1016/j.palaeo.2014.10.010.

Ogg, J.G., 2012a. 5 - Geomagnetic polarity time scale. In: Gradstein, F.M., Ogg, J.G., Schmitz, M.D., Ogg, G.M. (Eds.), The Geologic Time Scale. Elsevier, Amsterdam, pp. 85-113. https://doi.org/10.1016/B978-0-444-59425-9.00005-6.

Ogg, J.G., 2012b. 25 - Triassic. In: Gradstein, F.M., Ogg, J.G., Schmitz, M.D., Ogg, G.M. (Eds.), The Geologic Time Scale. Elsevier, Amsterdam, pp. 681-730. https://doi.org/ 10.1016/B978-0-444-59425-9.00025-1.

Ogg, J.G., Ogg, G.M., Gradstein, F.M., 2016. 11 - Triassic. In: Ogg, J.G., Ogg, G.M., Gradstein, F.M. (Eds.), A Concise Geologic Time Scale. Elsevier, Amsterdam, pp. 133-149. https://doi.org/10.1016/B978-0-444-59467-9.00011-X.

Olsen, P.E., Kent, D.V., 1999. Long-period Milankovitch cycles from the Late Triassic and Early Jurassic of eastern North America and their implications for the calibration of the Early Mesozoic time-scale and the long-term behavior of the planets. Philos. Trans. R. Soc. Lond. 357 (1757), 1761-1789. https://doi.org/10.1098/rsta.1999. 0400 .

Olsen, P.E., Kent, D.V., Whiteside, J.H., 2011. Implications of the Newark Supergroupbased astrochronology and geomagnetic polarity time scale (Newark-APTS) for the tempo and mode of the early diversification of the Dinosauria. Earth and Environmental Science Trans. R. Soc. Edinb. Earth Sci. 101 (3-4), 201-229. https:// doi.org/10.1017/S1755691011020032.

Olsen, P.E., Reid, J.C., Taylor, K.B., Whiteside, J.H., Kent, D.V., 2015. Revised Stratigraphy of Late Triassic Age Strata of the Dan River Basin (Virginia and North Carolina, USA) based on Drill Core and Outcrop Data. Southeast. Geol. 51 (1), 1-31.

Onoue, T., Yamashita, K., Fukuda, C., Soda, K., Tomimatsu, Y., Abate, B., Rigo, M., 2018 Sr isotope variations in the Upper Triassic succession at Pizzo Mondello, Sicily: constraints on the timing of the Cimmerian Orogeny. Palaeogeogr. Palaeoclimatol. Palaeoecol. 499, 131-137. https://doi.org/10.1016/j.palaeo.2018.03.025.

Orchard, M.J., 2008. Lower Triassic conodont from the Canadian Arctic, their intercalibration with ammonoid-based stages and a comparison with other North American Olenekian fauna. Polar Res. 27 (3), 393-412. https://doi.org/10.1111/j. 1751-8369.2008.00072.x

Orchard, M.J., Tozer, E.T., 1997. Triassic conodont biochronology, its calibration with the ammonoid standard and a biostratigraphic summary for the western Canada sedimentary basin. Bull. Can. Petrol. Geol. 45 (4), 675-692.

Payne, J.L., Lehrmann, D.J., Wei, J., Orchard, M.J., Schrag, D.P., Knoll, A.H., 2004. Large perturbations of the carbon cycle during recovery from the end-Permian extinction. Science 23, 506-509. https://doi.org/10.1126/science.1097023.

Peng, Y., Tong, J., Shi, G.R., Hansen, H.J., 2001. The Permian-Triassic boundary stratigraphic set: characteristics and correlation. Newsl. Stratigr. 39 (1), 55-71. https:// doi.org/10.1127/nos/39/2001/55.

Planke, S., Cerney, B., Bücher, C.J., Nilsen, O., 1999. Alteration effects on petrophysical properties of subaerial flood basalts: site 990, Southeast Greenland margin. In: Larsen, H.C., Duncan, R.A., Allan, J.F., Brooks, K. (Eds.), Proceedings of the Ocean Drilling Program, Scientific Results. vol. 163. pp. 17-28.

Preto, N., Hinnov, L.A., Hardie, L.A., De Zanche, V., 2001. Middle Triassic orbital signature recorded in the shallow-marine Latemar carbonate buildup (Dolomites, Italy). Geology 29 (12), 1123-1126. https://doi.org/10.1130/0091-7613(2001) $029<1123$ :MTOSRI > 2.0.CO;2. 
Preto, N., Hinnov, L.A., De Zanche, V., Mietto, P., Hardie, L.A., 2004. The Milankovitch interpretation of the Latemar platform cycles (Dolomites, Italy): implications for geochronology, biostratigraphy, and Middle Triassic carbonate accumulation. In: D'Argenio, B., Fischer, A.G., Premoli Silva, I., Weissert, H., Ferreri, V. (Eds.), Cyclostratigraphy: Approaches and Case Histories. vol. 81. SEPM, Special Publications, pp. 167-182.

Richoz, S., Krystyn, L., Spotl, C., 2007. Towards a carbon isotope reference curve of the Upper Triassic. In: Lucas, S.G., Spielmann, J.A. (Eds.), The Global Triassic. vol. 41. New Mexico Museum of Natural History and Science Bulletin, pp. 366-367.

Rigo, M., Preto, N., Roghi, G., Tateo, F., Mietto, P., 2007. A rise in the Carbonate Compensation Depth of western Tethys in the Carnian (Late Triassic): Deep-water evidence for the Carnian Pluvial Event. Palaeogeogr. Palaeoclimatol. Palaeoecol. 246, 188-205. https://doi.org/10.1016/j.palaeo.2006.09.013.

Rigo, M., Preto, N., Franceschi, M., Guaiumi, C., 2012. Stratigraphy of the Carnian-Norian Calcari con Selce Formation in the Lagonegro Basin, southern Apennines. Riv. Ital. Paleontol. Stratigr. 118 (1), 143-154. https://doi.org/10.13130/2039-4942/5995.

Rigo, M., Bertinelli, A., Cocnheri, G., Gattolin, G., Godfrey, L., Katz, M.E., Maron, M., Mietto, P., Muttoni, G., Sprovieri, M., Stellin, F., Zaffani, M., 2016. The PignolaAbriola section (southern Apennines, Italy): a new GSSP candidate for the base of the Rhaetian Stage. Lethaia 49 (3), 287-306. https://doi.org/10.1111/let.12145.

Rigo, M., Mazza, M., Karádi, V., Nicora, A., 2018. New Upper Triassic conodont biozonation on of the Tethyan Realm. In: Tanner, L.H. (Ed.), The Late Triassic World: Earth in a Time of Transition. Topics in Geobiology. vol. 46. pp. 189-235. https://doi.org/ 10.1007/978-3-319-68009-5_6.

Romano, C., Goudemand, N., Vennemann, T.W., Ware, D., Schneebeli-Hermann, E., Hochuli, P.A., Brühwiler, T., Brinkmann, W., Bucher, H., 2013. Climatic and biotic upheavals following the end-Permian mass extinction. Nat. Geosci. 6, 57-60. https:// doi.org/10.1038/ngeo1667.

Schoene, B., Guex, J., Bartolini, A., Schaltegger, U., Blackburn, T.J., 2010. Correlating the end-Triassic mass extinction and flood basalt volcanism at the $100 \mathrm{ka}$ level. Geology 38 (5), 387-390. https://doi.org/10.1130/G30683.1.

Scholger, R., Mauritsch, H.J., Brandner, R., 2000. Permian-Triassic boundary magnetostratigraphy from the southern Alps (Italy). Earth Planet. Sci. Lett. 176 (3-4), 495-508. https://doi.org/10.1016/S0012-821X(00)00026-1.

Shen, S.-z., Crowley, J.L., Wang, Y., Bowring, S.A., Erwin, D.H., Sadler, P.M., Cao, C.-q., Rothman, D.H., Henderson, C.M., Ramezani, J., Zhang, H., Shen, Y., Wang, X.-d., Wang, W., Mu, L., Li, W.-z., Tang, Y.-g., Liu, X.-1., Liu, L.-j., Zeng, Y., Jiang, Y.-f., Jin, Y.-g., 2011. Calibrating the End-Permian mass extinction. Science 334 (6061), 1367-1372. https://doi.org/10.1126/science.1213454.

Spahn, Z.P., Kodama, K.P., Preto, N., 2013. High-resolution estimate for the depositional duration of the Triassic Latemar Platform: a new magnetostratigraphy and magnetic susceptibility cyclostratigraphy from basinal sediments at Rio Sacuz, Italy. Geochem. Geophys. Geosyst. 14 (4), 1245-1257. https://doi.org/10.1002/ggge.20094.

Stefani, M., Furin, S., Gianolla, P., 2010. The changing climate framework and depositional dynamics of Triassic carbonate platforms from the Dolomites. Palaeogeogr. Palaeoclimatol. Palaeoecol. 290 (1-4), 43-57. https://doi.org/10.1016/j.palaeo. 2010.02.018.

Steiner, M.B., Ogg, J., Zhang, Z., Sun, S., 1989. The Late Permian/Early Triassic magnetic polarity time scale and plate motions of south China. J. Geophys. Res. 94 (B6), 7343-7363. https://doi.org/10.1029/JB094iB06p07343.

Storck, J.-C., Brack, P., Wotzlaw, J.-F., Ulmer, P., 2018. Timing and evolution of Middle Triassic magmatism in the Southern Alps (Northern Italy). J. Geol. Soc. https://doi. org/10.1144/jgs2018-123.

Sun, Z., Hounslow, M.W., Pei, J., Zhao, L., Tong, J., Ogg, J.G., 2007. Magnetostratigraphy of the West Pingdingshan section, Chaohu, Anhui Province: relevance for base Olenekian GSSP selection. Albertiana 36, 22-32.

Sun, Z., Hounslow, M.W., Pei, J., Zhao, L., Tong, J., Ogg, J.G., 2009. Magnetostratigraphy of the Lower Triassic beds from Chaohu (China), and its implications for the InduanOlenekian stage boundary. Earth Planet. Sci. Lett. 279 (3-4), 350-361. https://doi. org/10.1016/j.epsl.2009.01.009.

Szurlies, M., 2004. Magnetostratigraphy: the key to a global correlation of the classic German Trias - case study Volpriehausen Formation (Middle Bundsandstein), Central
Germany. Earth Planet. Sci. Lett. 227 (3-4), 395-410. https://doi.org/10.1016/j. epsl.2004.09.011.

Szurlies, M., 2007. Latest Permian to Middle Triassic cyclo-magnetotratigraphy from the Central European Basin, Germany: implications for the geomagnetic polarity timescale. Earth Planet. Sci. Lett. 261 (3-4), 602-619. https://doi.org/10.1016/j.epsl. 2007.07.018.

Tanner, L.H., 2010. The Triassic isotope record. In: Lucas, S.G. (Ed.), The Triassic Timescale. vol. 334. Geological Society of London, Special Publications, pp. 103-118. https://doi.org/10.1144/SP334.5.

Van de Schootbrugge, B., Payne, J.L., Tomasovych, A., Pross, J., Fiebig, J., Benbrahim, M., Follmi, K.B., Quan, T.M., 2008. Carbon cycle perturbation and stabilization in the wake of the Triassic-Jurassic boundary mass extinction event. Geochem. Geophys. Geosyst. 9 (4), 1-16. https://doi.org/10.1029/2007GC001914.

Ward, P.D., Garrison, G.H., Haggart, J.W., Kring, D.A., Beattie, M.J., 2004. Isotopic evidence bearing on the Late Triassic extinction events, Queen Charlotte Islands, British Columbia, and implications for the duration and the cause of the Triassic/Jurassic mass extinction. Earth Planet. Sci. Lett. 224 (3-4), 589-600. https://doi.org/10. 1016/j.epsl.2004.04.034.

Whiteside, J.H., Ward, P.D., 2011. Ammonoid diversity and disparity track episodes of chaotic carbon cycling during the early Mesozoic. Geology 39 (2), 99-102. https:// doi.org/10.1130/G31401.1.

Wotzlaw, J.-F., Guex, J., Bartolini, A., Gallet, Y., Krystyn, L., McRoberts, C.A., Taylor, D., Schoene, B., Schaltegger, U., 2014. Towards accurate numerical calibration of the Late Triassic: high-precision U-Pb geochronology constraints on the duration of the Rhaetian. Geology 42, 571-574. https://doi.org/10.1130/G35612.1.

Wotzlaw, J.-F., Brack, P., Storck, J.-C., 2018. High-resolution stratigraphy and zircon U$\mathrm{Pb}$ geochronology of the Middle Triassic Buchenstein Formation (Dolomites, northern Italy): precession-forcing of hemipelagic carbonate sedimentation and calibration of the Anisian-Ladinian boundary interval. J. Geol. Soc. 175, 71-85. https://doi.org/10. 1144/jgs2017-052.

Yin, H., Zhang, K., Tong, J., Yang, Z., Wu, S., 2001. The Global Stratotype Section and Point (GSSP) of the Permian-Triassic boundary. Episodes 24, 102-114.

Zaffani, M., Agnini, C., Concheri, G., Godfrey, L., Katz, M., Maron, M., Rigo, M., 2017. The Norian "chaotic carbon interval": new clues from $\delta^{13} \mathrm{C}_{\text {org }}$ record of the Lagonegro Basin (southern Italy). Geosphere 13 (4), 1133-1148. https://doi.org/10.1130/ GES01459.1.

Zaffani, M., Jadoul, F., Rigo, M., 2018. A new Rhaetian $\delta^{13} C_{\text {org }}$ record: carbon cycle disturbances, volcanism, End-Triassic mass Extinction (ETE). Earth Sci. Rev. 178, 92-104. https://doi.org/10.1016/j.earscirev.2018.01.004.

Zhang, Y., Li, M., Ogg, J.G., Montgomery, P., Huang, C., Chen, Z.-Q., Shi, Z., Enos, P., Lehrmann, D.J., 2015. Cycle-calibrated magnetostratigraphy of middle Carnian from South China: implications for Late Triassic time scale and termination of the Yangtze Platform. Palaeogeogr. Palaeoclimatol. Palaeoecol. 436, 135-166. https://doi.org/ 10.1016/j.palaeo.2015.05.033.

Zhao, L., Orchard, M.J., Tong, J., Sun, Z., Zuo, J., Zhang, S., Yun, A., 2007. Lower Triassic conodont sequence in Chaohu, Anhui Province, China and its global correlation. Palaeogeogr. Palaeoclimatol. Palaeoecol. 252 (1-2), 24-38. https://doi.org/10. 1016/j.palaeo.2006.11.032.

Zhao, L., Tong, J., Sun, Z., Orchard, M.J., 2008. A detailed Lower Triassic conodont biostratigraphy and its implications for the GSSP candidate of the Induan-Olenekian boundary in Chaohu, Anhui Province. Prog. Nat. Sci. 18 (1), 79-90. https://doi.org/ 10.1016/j.pnsc.2007.07.001.

Zijderveld, J.D.A., 1967. A.C. demagnetization of rocks: analysis of results. In: Collinson, D.W., Creer, K.M., Runcorn, S.K. (Eds.), Methods in Paleomagnetism. Elsevier, Amsterdam, pp. 254-286.

Zou, X., Balini, M., Jiang, D.-y., Tintori, A., Sun, Z.-y., Sun, Y.-1., 2015. Ammonoids from the Zhuganpo Member of the Falang Formation at Nimaigu and their relevance for dating the Xingyi fossil-lagerstatte (late Ladinian, Guizhou, China). Riv. Ital. Paleontol. Stratigr. 121 (2), 135-161. https://doi.org/10.13130/2039-4942/6511.

Zühlke, R., Bechstädt, T., Mundil, R., 2003. Sub-Milankovitch and Milankovitch forcing on a model Mesozoic carbonate platform - the Latemar (Middle Triassic, Italy). Terra Nova 15 (2), 69-80. https://doi.org/10.1046/j.1365-3121.2003.00366.x. 